\title{
Physiological insights into sulfate and selenium interaction to improve drought tolerance in mung bean
}

\author{
Muhammad Aqib $^{1} \cdot$ Fahim Nawaz $^{1,2,8}$ (D) $_{\text {Sadia Majeed }}{ }^{3}$ Abdul Ghaffar ${ }^{1} \cdot$ \\ Khawaja Shafique Ahmad $^{4} \cdot$ Muhammad Asif Shehzad $^{1} \cdot$ Muhammad Naem Tahir $^{5}$. \\ Muhammad Aurangzaib ${ }^{3}$ - Hafiz Muhammad Rashad Javeed ${ }^{6}$. \\ Muhammad Habib-ur-Rahman ${ }^{1,7}$ - Muhammad Munir Usmani ${ }^{1}$
}

Received: 22 July 2020/Revised: 31 March 2021 / Accepted: 6 April 2021/Published online: 4 May 2021

(C) The Author(s) 2021

\begin{abstract}
The present study involved two pot experiments to investigate the response of mung bean to the individual or combined $\mathrm{SO}_{4}{ }^{2-}$ and selenate application under drought stress. A marked increment in biomass and NPK accumulation was recorded in mung bean seedlings fertilized with various $\mathrm{SO}_{4}{ }^{2-}$ sources, except for $\mathrm{CuSO}_{4}$. Compared to other $\mathrm{SO}_{4}{ }^{2-}$ fertilizers, $\mathrm{ZnSO}_{4}$ application resulted in the highest increase in growth attributes and shoot nutrient content. Further, the combined $\mathrm{S}$ and $\mathrm{Se}$ application $(\mathrm{S}+\mathrm{Se})$ significantly enhanced relative water content $(16 \%)$, SPAD value $(72 \%)$, photosynthetic rate $(80 \%)$ and
\end{abstract}

Supplementary Information The online version contains supplementary material available at https://doi.org/10.1007/s12298021-00992-6.

Fahim Nawaz

fahim.nawaz@uni-hohenheim.de; fahim5382@gmail.com

1 Department of Agronomy, MNS University of Agriculture, Multan, Pakistan

2 Institute of Crop Science (340 h), University of Hohenheim, Stuttgart, Germany

3 Department of Agronomy, The Islamia University of Bahawalpur, Bahawalpur, Pakistan

4 Department of Botany, University of Poonch, Rawalakot 12350, Pakistan

5 University College of Veterinary and Animal Sciences, The Islamia University of Bahawalpur, Bahawalpur, Pakistan

6 Department of Environmental Sciences, COMSATS University, Vehari Campus, Vehari, Pakistan

7 Institute of Crop Science and Resource Conservation (INRES) Crop Science, University Bonn, Bonn, Germany

8 Present Address: Alexander von Humboldt Postdoctoral Fellow at University of Hohenheim (340 h), 70599 Stuttgart, Germany activities of catalase (79\%), guaiacol peroxidase (53\%) and superoxide dismutase (58\%) in the leaves of water-stressed mung bean plants. Consequently, the grain yield of mung bean was markedly increased by $105 \%$ under water stress conditions. Furthermore, $\mathrm{S}+\mathrm{Se}$ application considerably increased the concentrations of $\mathrm{P}(47 \%), \mathrm{K}(75 \%), \mathrm{S}$ (80\%), $\mathrm{Zn}(160 \%)$, and $\mathrm{Fe}(15 \%)$ in mung bean seeds under drought stress conditions. These findings indicate that $\mathrm{S}+\mathrm{Se}$ application potentially increases the nutritional quality of grain legumes by stimulating photosynthetic apparatus and antioxidative machinery under water deficit conditions. Our results could provide the basis for further experiments on cross-talk between $\mathrm{S}$ and Se regulatory pathways to improve the nutritional quality of food crops.

Keywords Sulfate Selenate Photosynthetic apparatus · Mineral content $\cdot$ Drought $\cdot$ Vigna radiata

\section{Introduction}

Climate change has increased the vulnerability of cropping systems, which may trigger a loss of livelihoods of poor communities in arid and semi-arid regions of the world (Leng and Hall 2019). The imbalance in the temporal and spatial distribution of rainfall and the non-availability of the required amount of water during critical growth stages would seriously limit the productivity of major food crops in near future (Troy et al. 2015). The non-availability of water severely hampers crop production in developing and arid regions of the world where people are solely dependent on rainwater for their survival. Detrimental effects of drought are likely to aggravate the world's limiting available fresh water supply to fulfill the food demand for the ever-increasing population (Leng 2017). In this regard, it is 
imperative to recognize the importance of climate-resilient crops such as legumes and promote their value throughout the food systems.

Legumes are an integral part of a healthy and balanced human diet and play important role in preventing many acute diseases. Moreover, due to their atmospheric nitrogen (N) fixing ability, they increase soil $\mathrm{C}$ and $\mathrm{N}$, reduce soil erosion and help to control soil pathogens (Rubiales and Mikic 2015). Mung bean (Vigna radiata (L.) R. Wilczek) is an important food legume that is grown primarily for dry seeds (Kudre et al. 2013). Although, mung bean is considered tolerant to limited water supply, low water availability at reproductive and grain filling stages significantly reduces its yield and quality (Gaur et al. 2012). Droughtinduced changes in mung bean include reduced carbon fixation, repressed flowering time, increased pollen sterility, fewer pods, and poor seed set (Nadeem et al. 2019). Legume crops like mung bean are commonly cultivated in rainfed regions; hence, development of sustainable mitigation approaches that could easily integrate with farming practices of dry areas is essential to ensure high yield under harsh environment (Raina et al. 2016). Application of mineral nutrients actively involved in stress tolerance and defense mechanisms could be used as a viable option to alleviate the damaging effects of environmental stresses in legumes (Afzal et al. 2015).

Sulfur (S) is an important element that plays a crucial role to mitigate abiotic stresses in crop plants. Increased sulfate $\left(\mathrm{SO}_{4}{ }^{2-}\right)$ demand during metabolic adaptation to drought reflects its importance in the regulation of plant defense machinery (Usmani et al. 2020). Drought stress increases the concentration of $\mathrm{SO}_{4}{ }^{2-}$ compared to other ions like phosphate or nitrate, providing evidence that sulfate demand increases under limited water conditions (Ernst et al. 2010). $\mathrm{SO}_{4}{ }^{2-}$ interacts with abscisic acid (ABA) and acts as a chemical signal to initiate stomatal closure in leaves under water deficit conditions. Metabolism of $\mathrm{S}$ results in the formation of several S-containing defense compounds such as methionine, cysteine, glutathione, and phytochelatins that are involved in plant survival during various abiotic stresses including drought (Honsel et al. 2012). The interplay of S with phytohormones helps to regulate crucial metabolic processes in plants (Noctor et al. 2012). Deficiency of S may result in impaired growth, loss in plant production, and susceptibility to environmental stresses due to reduced protein synthesis, chlorophyll degradation and decreased photosynthetic rate (Fatma et al. 2016).

Akin to $\mathrm{S}$, selenium $(\mathrm{Se})$ is an important micronutrient considered essential for animals and required in very minute quantities by plants. Both Se and $\mathrm{S}$ share similar chemical properties and are taken up by plants through sulfate transporters and assimilated by $\mathrm{S}$ assimilating pathway (Sors et al. 2005). In most countries, the major dietary source of Se is plant food (Rayman 2008). Se deficiency in the human diet causes abnormalities in thyroid function alters bone metabolism, and leads to retarded growth (Reeves and Hoffman 2009). In Se deficient areas, exogenous application with $\mathrm{Se}$ or Se-enriched compounds can be used as an efficient, cost-effective and viable approach to enrich plants with Se (Sabatino et al. 2019). Moreover, Se application stimulates growth, improves physiological processes (Bocchini et al. 2018), and enhances tolerance against various environmental stresses (Banerjee and Roychoudhury 2019). It is considered as a constituent of selenoenzymes (thioredoxin reductases, glutathione peroxidase, and proteins), which are vital to maintaining cell redox potential (Rayman 2008). Se increases plant growth (Nawaz et al. 2013), carbohydrate accumulation (Kaur et al. 2018), and delays senescence in crop plants (Hajiboland et al. 2019). The positive effects of Se to mitigate biotic and abiotic stresses including UV-B radiation (Golob et al. 2017), cadmium toxicity (Shahid et al. 2019), fungal infections (Kornaś et al. 2019), and drought (Nawaz et al. 2015a) are well documented.

To date, only few studies have been conducted to investigate the yield changes in leguminous crops like mung bean by Se supply under drought stress. This study partially fills the gap by determining the effects of $\mathrm{Se}$ application and its interrelation with $\mathrm{S}$ in mung bean exposed to water deficit conditions. The study aimed to i) evaluate the effects of Se or S nutrition on physiological mechanisms of mung bean under drought stress and ii) assess whether combined application of Se and $\mathrm{S}$ is more effective than individual treatment to improve yield and mineral content of mung bean under water deficit conditions.

\section{Materials and Methods}

\section{Experimental conditions and material}

The experiments were conducted in two phases: initially, the locally cultivated mung bean cultivars were screened for their response to various $\mathrm{S}$ fertilizers in the first experiment. Later in the second experiment, the most responsive mung bean cultivar was evaluated for its response to individual or combined $\mathrm{S}$ and $\mathrm{Se}$ doses under normal and water-deficient conditions. The experiments were performed in a green house (C-block, MNS-University of Agriculture, Multan, Pakistan) with ambient temperature (average day/night: $36 / 23{ }^{\circ} \mathrm{C}$ ) and light (photoperiod: $14 / 10 \mathrm{~h}$ ) conditions during the growth period. A manually controlled moveable polythene sheet was installed to protect the plants from rainwater. The 
experimental design was completely randomized design (CRD) with the factorial arrangement and three replications (03 plants per replication/pot were maintained till final harvest). The pot experiment-I comprised of 45 pots, whereas 36 pots were used in the pot-experiment-II. The pots were filled with sun-dried, grounded, and thoroughly mixed clayey-loamy soil collected from the farm area of the University located at B-block. The physicochemical characteristics of the soil were determined following the reports of Jackson and Barak (2005) and given in Table 1.

\section{Pot experiment-I}

The first experiment was conducted with the objective to evaluate the response of mung bean cultivars to various S-sources. The experiment was initiated on May 06, 2018, for four weeks. Seeds of three local mung bean cultivars viz. NM-2006, NM-2011, and AZRI-2006 were obtained from Punjab Seed Corporation, Faisalabad (Pakistan). Initially, six healthy and physically pure seeds were sown in pots with $15 \mathrm{~L}$ capacity (height $25 \mathrm{~cm}$ and diameter $30 \mathrm{~cm}$ ), and each filled with $12 \mathrm{~kg}$ clayey-loamy soil. After the establishment of seedlings, thinning was done to maintain three healthy plants per pot. Before sowing, recommended doses of fertilizers such as urea $\left(25 \mathrm{~kg} \mathrm{ha}^{-1}\right.$,

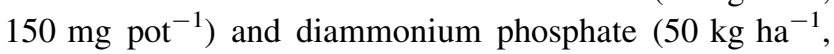
$\left.300 \mathrm{mg} \mathrm{pot}{ }^{-1}\right)$, and potassium hydroxide $\left(50 \mathrm{~kg} \mathrm{ha}^{-1}\right.$, $300 \mathrm{mg} \mathrm{pot}^{-1}$ ) were added as nutrient solutions to meet the nutritional requirement of the plants in each pot. To ensure that each pot received an equal amount of $\mathrm{S}\left(20 \mathrm{~kg} \mathrm{ha}^{-1}\right.$, $120 \mathrm{mg} \mathrm{pot}^{-1}$ ), different fertilizer treatments of zinc sulfate $\left(\mathrm{ZnSO}_{4}, 1090 \mathrm{mg} \mathrm{pot}^{-1}\right)$, iron sulfate $\left(\mathrm{FeSO}_{4}, 571 \mathrm{mg}\right.$ pot $\left.^{-1}\right)$, potassium sulfate $\left(\mathrm{K}_{2} \mathrm{SO}_{4}, 667 \mathrm{mg} \mathrm{pot}^{-1}\right)$, and copper sulfate $\left(\mathrm{CuSO}_{4}, 923 \mathrm{mg} \mathrm{pot}^{-1}\right)$ were added through fertigation in each pot. After four weeks, the seedlings were harvested to determine the effects of S fertilization on biomass accumulation and nutrient uptake in different mung bean cultivars. The seedlings were washed thoroughly to avoid any sand particles and the samples were packed in plastic bags and tagged according to the treatments.

\section{Pot-experiment II}

In this experiment, the role of $\mathrm{S}$ and/or $\mathrm{Se}$ nutrition to improve the growth and yield of mung bean under drought stress was investigated. The best performing mung bean cultivar i.e. AZRI-2006, selected from pot-experiment-I, was evaluated for its response to individual or combined $S$ and Se nutrition. The S-fertilizer $\left(\mathrm{ZnSO}_{4}, 1090 \mathrm{mg} \mathrm{pot}^{-1}\right)$ was selected based on results of pot-experiment I and was evaluated alone or in combination with two Se doses i.e. $\mathrm{Se}_{1}\left(2 \mu \mathrm{mol} \mathrm{Se} \mathrm{L}^{-1}\right)$ and $\mathrm{Se}_{2}\left(4 \mu \mathrm{mol} \mathrm{Se} \mathrm{L}^{-1}\right)$ using sodium selenate $\left(\mathrm{Na}_{2} \mathrm{SeO}_{4}\right)$ as a source of Se. The experiment was conducted during the growth period of 2018 (June 14 to September 20). Physically pure and healthy seeds of selected mung bean cultivar (AZRI-2006) were sown in brick pots, as described in pot-experiment-I. The nutritional requirements in the form of $\mathrm{N}, \mathrm{P}$, and $\mathrm{K}$ along with $\mathrm{ZnSO}_{4}$ were fulfilled at the start of the experiment (two days before sowing) as described earlier, whereas $\mathrm{Se}$ treatments as foliar spray were done one week after the onset of drought.

\section{Drought stress and foliar Se treatment}

All pots were watered regularly considering the moisture requirements calculated using the method reported by Giriappa (1988). The seedlings were allowed to establish under normal conditions for the first two weeks and then drought stress was initiated by withholding water supply for the next 15 days to one set of pots (drought stress) compared to normal plants watered at regular intervals. Foliar spray of Se was done one week after the initiation of drought using compression sprayer as described by Nawaz et al. (2015a) and repeated the next week on the same day. The spraying was done manually in the early hours of the morning (between 8:00 and 9:00 a.m.) and each treatment solution was added with Tween-20 $(0.1 \%)$ to enhance the adhesion of Se to foliage. Data regarding gas exchange characteristics was recorded two days after the second spray, whereas the leaf samples for physiological and biochemical analysis were collected the very next day. The plants were grown till maturity and harvested manually at physiological maturity when about more than $80 \%$ of pods turned yellow.

\section{Morphological attributes and shoot NPK content}

The seedlings were manually uprooted to collect data regarding biomass accumulation. The soil around the seedlings was dug deep and seedlings were removed with extreme care to minimize damage to the roots. A metering rod was used for the measurement of the root length (RL)
Table 1 Physico-chemical characteristics of soil used in the pots for the experiments

\begin{tabular}{lllllllll}
\hline Texture & $\begin{array}{l}\text { Soil moisture content } \\
(\%)\end{array}$ & $\begin{array}{l}\mathrm{EC} \\
\left(\mathrm{mScm}^{-1}\right)\end{array}$ & $\mathrm{pH}$ & $\begin{array}{l}\mathrm{OM} \\
(\%)\end{array}$ & $\begin{array}{l}\mathrm{N} \\
(\%)\end{array}$ & $\begin{array}{l}\mathrm{P} \\
\left(\mathrm{mg} \mathrm{kg}^{-1}\right)\end{array}$ & $\begin{array}{l}\mathrm{K} \\
\left(\mathrm{mg} \mathrm{kg}^{-1}\right)\end{array}$ & $\begin{array}{l}\mathrm{S} \\
(\%)\end{array}$ \\
\hline Loamy sand & 11.2 & 2.47 & 7.9 & 0.74 & 0.076 & 8.50 & 240 & 0.032 \\
\hline
\end{tabular}


of each seedling. Observed data from selected plants were recorded in $\mathrm{cm}$ (centimeters) from the basal end of the root to the bottom of the shoot and the mean of three readings was calculated. The shoot length (SL) of above-ground part of each seedling was calculated in centimeters $(\mathrm{cm})$ using a meter rod. The seedlings were then weighed immediately to record shoot fresh weight (SFW) in grams (g) using a digital balance. The shoots were then placed in an oven at $65^{\circ} \mathrm{C}$ for $72 \mathrm{~h}$ to record shoot dry weight (SDW).

The oven-dried shoot samples (above ground material) were grounded and later these finely ground shoot samples $(0.5 \mathrm{~g})$ were acid digested using $5 \mathrm{ml} \mathrm{HNO}_{3}$ and $2 \mathrm{ml}$ $\mathrm{H}_{2} \mathrm{O}_{2}$ at $350{ }^{\circ} \mathrm{C}$ for three hours in digestion block. This was done until the solution becomes colorless. After digestion, the solution was cooled to room temperature and distilled water was added to make the final volume up to $50 \mathrm{ml}$. The shoot $\mathrm{N}$ content was determined by Kjeldahl method (AOAC 1984), whereas the Vanadium molybdate yellow calorimetric method (Chen et al. 1956), and Flame photometry (Karpiuk et al. 2016) were employed to estimate $\mathrm{P}$ and $\mathrm{K}$ contents in shoots, respectively.

\section{Estimation of leaf water status and SPAD value}

The leaf water status of normal and drought-stressed mung bean plants was estimated as leaf relative water content (RWC) using leaf samples ( $0.5 \mathrm{~g})$ from the uppermost fully expanded leaf (Schonfeld et al. 1988). The leaves were weighed immediately (FW), re-hydrated in distilled water for $24 \mathrm{~h}$ in the refrigerator $\left(4^{\circ} \mathrm{C}\right)$ to record turgid weight (TW), and later dried in an oven at $70{ }^{\circ} \mathrm{C}$ until constant weight (DW) was obtained. Leaf RWC was calculated as $100 \times(\mathrm{FW}-\mathrm{TW}) /(\mathrm{FW}-\mathrm{DW})$.

Randomly selected top five fully expanded leaves were selected in each pot to measure leaf total chlorophyll content (Chl) using SPAD meter (SPAD-502 plus, KonicaMinolta, Beijing, China). The readings were used to calculate the average SPAD value for each treatment.

\section{Measurement of leaf gas exchange characteristics}

The leaf gas exchange characteristics viz. photosynthetic rate $(A)$, stomatal conductance $\left(g_{s}\right)$, sub-stomatal conductance $\left(C_{i}\right)$, and transpiration rate $(E)$ were recorded from the second fully expanded young mature leaf from the top using portable photosynthesis system CIRAS-3 (PP Systems, Amesbury, U.S.A.). These observations were made in the morning between 8:00 and 10:00 with the adjustments as reported in Shehzad et al. (2020).

\section{Antioxidative enzymes assay}

Fresh leaf samples $(0.5 \mathrm{~g})$ were homogenized in an icecold mortar and pestle $(1: 5 \mathrm{w} / \mathrm{v})$ using a mixture of sodium phosphate buffer $(50 \mathrm{mM}, \mathrm{pH} 7.0)$, polyvinylpyrrolidone (1\%), EDTA (1 mM), and $\mathrm{NaCl}(1 \%)$. The crude extract was centrifuged at $20,000 \times \mathrm{xg}$ for $15 \mathrm{~min}$ and the supernatant, denoted as enzyme extract (EE), was used to determine the antioxidant enzyme activity.

Catalase (CAT) activity was determined following the procedure of Aebi (1984). Briefly, $200 \mu \mathrm{L}$ EE was added to $1.8 \mathrm{~mL}$ RM (reaction mixture) prepared by mixing K-Pbuffer $(50 \mathrm{mM}, \mathrm{pH} 7.0)$ and $\mathrm{H}_{2} \mathrm{O}_{2}(30 \mathrm{mM})$. The degradation of $\mathrm{H}_{2} \mathrm{O}_{2}$ was recorded as a reduction in optical density at $240 \mathrm{~nm}$.

The method published by Urbanek et al. (1991) was followed to determine the leaf guaiacol peroxidase (GPX) activity. Initially, $25 \mu \mathrm{L}$ EE was added to $2 \mathrm{ml}$ solution prepared by mixing K-P-buffer $(50 \mathrm{mM}, \mathrm{pH} 6.8), \mathrm{H}_{2} \mathrm{O}_{2}$ $(20 \mathrm{mM})$, and guaiacol $(20 \mathrm{mM})$. After incubation at room temperature for $10 \mathrm{~min}$, the reaction was stopped by adding $0.5 \mathrm{~mL} \mathrm{H}_{2} \mathrm{SO}_{4}(5 \% \mathrm{v} / \mathrm{v})$ and the absorbance was noted at $480 \mathrm{~nm}$.

The enzyme activity of superoxide dismutase (SOD) was assayed by adding $50 \mu \mathrm{L}$ EE in $\mathrm{RM}$ containing L-methionine $(13 \mathrm{mM})$, NBT or nitro blue tetrazolium chloride $(75 \mu \mathrm{M})$, riboflavin $(2 \mu \mathrm{M}))$ and EDTA $(100 \mu \mathrm{M})$ in K-P-buffer ( $50 \mathrm{mM}, \mathrm{pH} 7.8)$. The reaction was initiated under the illumination of a $30 \mathrm{~W}$-fluorescent lamp for $5 \mathrm{~min}$, resulting in the formation of blue formazan measured as an increase in absorbance at $560 \mathrm{~nm}$ using RM (kept in the dark) as a blank (Van Rossum et al. 1997).

\section{Determination of yield components seed mineral content}

All plants were harvested manually at physiological maturity. The number of seeds in each pod was collected and then weighed to obtain 100-grain weight $(\mathrm{GW})$ for each treatment. The biological yield (BY) was determined by weighing the total plants in each pot and then the average was calculated. Similarly, grain yield (GY) was determined by weighing the total number of grains produced by plants per pot, and later average number of grains per plant was calculated.

Finely ground seeds $(0.2 \mathrm{~g})$ of each treatment were digested by $\mathrm{HNO}_{3}$ to determine the concentrations of mineral nutrients. The potassium $(\mathrm{K})$, zinc $(\mathrm{Zn})$, iron $(\mathrm{Fe})$, and manganese $(\mathrm{Mn})$ concentrations were measured following the method of Karpiuk et al. (2016) while the S content was determined according to Chandra and Pandey (2016) using atomic absorption spectrophotometry. Also, the seed $\mathrm{N}$ and $\mathrm{P}$ concentrations were measured on a UV- 
visible spectrophotometer (Hitachi-220, Hitachi Ltd, Tokyo, Japan) using Kjeldahl method (AOAC 1984) and molybdenum reaction solution method (Chen et al. 1956), respectively.

\section{Statistical analyses}

Fisher's ANOVA (analysis of variance) technique was employed to statistically analyze all recorded data using Statistix (Analytical Software, FL, USA, Version 8.1). The treatment means were compared using Tukey's posthoc HSD test at a $95 \%$ confidence level $(P<0.05)$.

\section{Results}

\section{Biomass attributes}

All biomass traits exhibited highly considerable $(P \leq 0.01)$ variation among mung bean cultivars (Suppl. Table 1). The cultivar AZRI-2006 maintained significantly higher SL $(12.64 \mathrm{~cm})$, RL $(12.12 \mathrm{~cm})$, SFW (0.72 g), and SDW (0.27 g) compared to NM-2006 and NM-2011 (Fig. 1). Among different $\mathrm{SO}_{4}{ }^{2-}$ fertilizers, $\mathrm{ZnSO}_{4}$ application resulted in the highest SL (37\%), RL (51\%), SFW (26\%), and SDW (25\%) in AZRI-2006 with respect to control. Application of $\mathrm{FeSO}_{4}$ and $\mathrm{K}_{2} \mathrm{SO}_{4}$ also improved the biomass of AZRI-2006 seedlings only, whereas $\mathrm{CuSO}_{4}$ markedly reduced these attributes in all mung bean cultivars (Fig. 1).

\section{Shoot NPK content}

Among mung bean cultivars, a marked variation for shoot NPK content was only noted for K accumulation as AZRI2006 exhibited 13 and $12 \%$ higher $\mathrm{K}$ content than NM2006 and NM-2011, respectively (Fig. 2c). However, different $\mathrm{S}$ fertilizers showed a significant effect on $\mathrm{N}, \mathrm{P}$, and $\mathrm{K}$ accumulation in shoots of mung bean cultivars $(P$ $\leq$ 0.01; Suppl. Table 1). Mung bean cultivars treated with $\mathrm{ZnSO}_{4}$ exhibited 25 and $9 \%$ higher shoot $\mathrm{N}$ content than $\mathrm{FeSO}_{4}$ and $\mathrm{K}_{2} \mathrm{SO}_{4}$, respectively (Fig. 2a). A similar trend was noted for shoot $\mathrm{P}$ content with a maximum increase $(25 \%)$ recorded in shoots of seedlings fertigated with $\mathrm{ZnSO}_{4}$ compared to control (no S fertilizer). Likewise, the $\mathrm{K}_{2} \mathrm{SO}_{4}$ application also improved shoot $\mathrm{P}$ content by $16 \%$, whereas no significant effect of $\mathrm{FeSO}_{4}$ and $\mathrm{CuSO}_{4}$ was observed on this variable (Fig. $2 \mathrm{~b}$ ). The shoot $\mathrm{K}$ content was increased by 30 and $21 \%$ in seedlings treated with $\mathrm{ZnSO}_{4}$ and $\mathrm{K}_{2} \mathrm{SO}_{4}$, respectively however, $\mathrm{CuSO}_{4}$ application did not affect $\mathrm{K}$ accumulation compared to control (Fig. 2c). a.

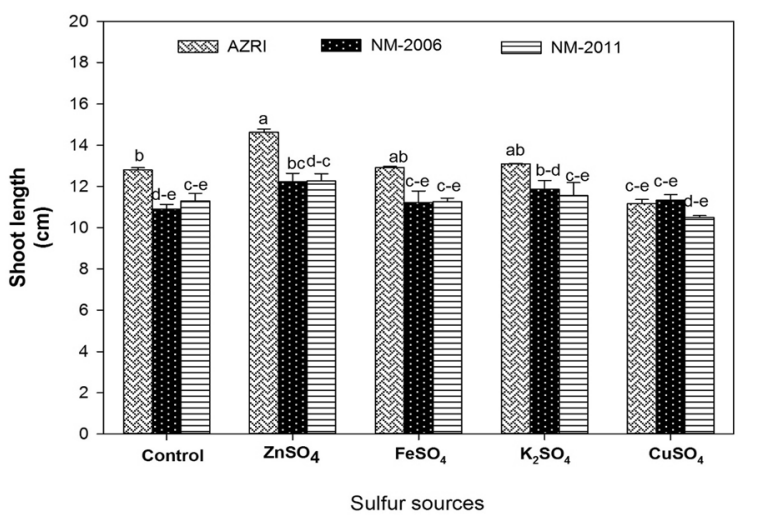

b.

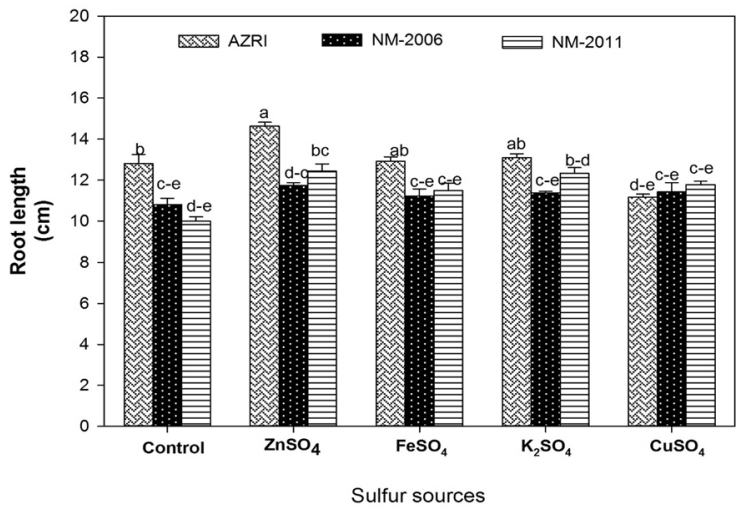

c.

d.
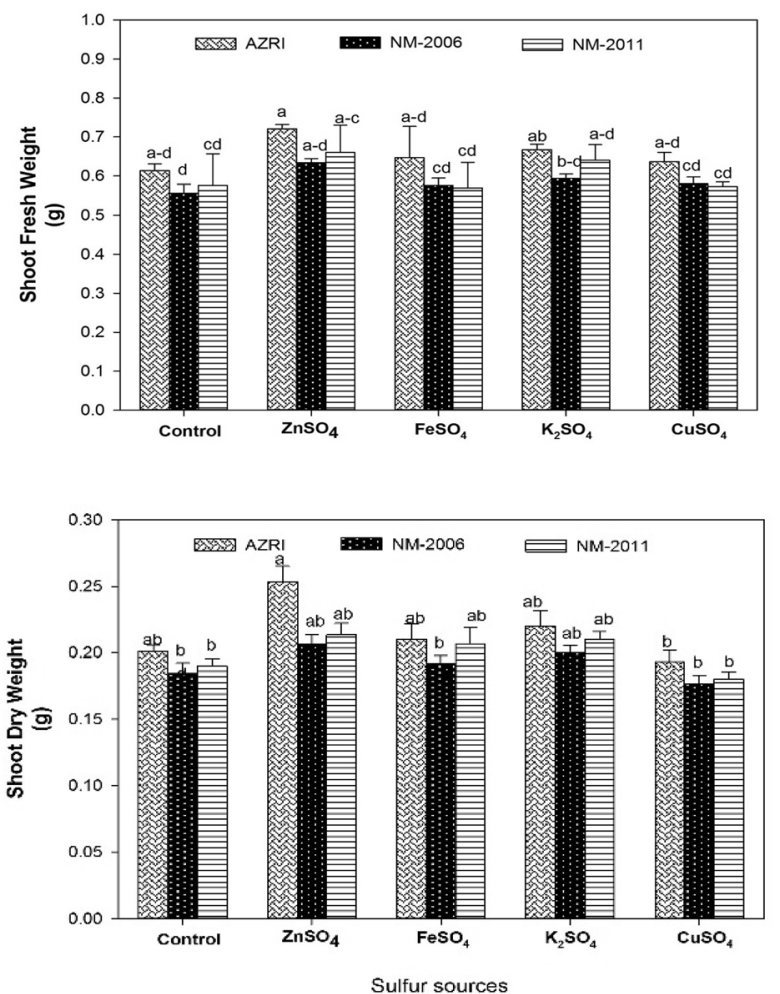
4Fig. 1 Effect of different $\mathrm{S}$-sources viz. no $\mathrm{S}$ supply (control), $\mathrm{ZnSO}_{4}, \mathrm{FeSO}_{4}, \mathrm{~K}_{2} \mathrm{SO}_{4}$ and $\mathrm{CuSO}_{4}$ on a shoot length, b root length c shoot fresh weight and $\mathbf{d}$ shoot dry weight of three mung bean cultivars (NM-2006, NM-2011 and AZRI-2006). Treatment means that are significantly different are represented by different letters, after applying post-hoc Tukey's HSD test

a.

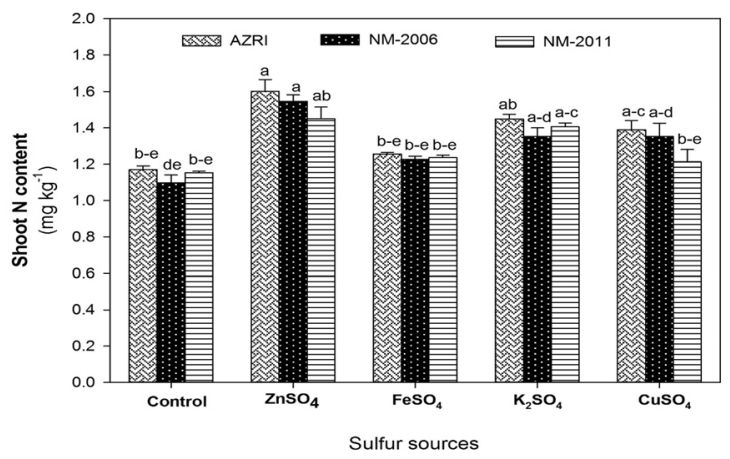

b.

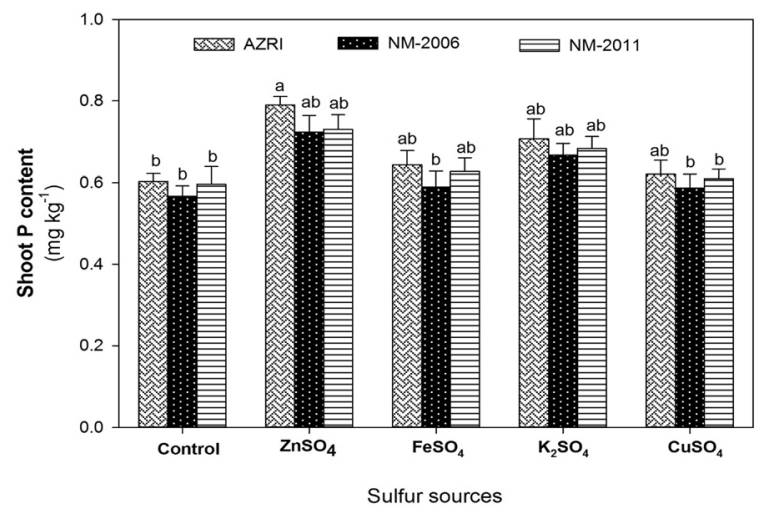

c.

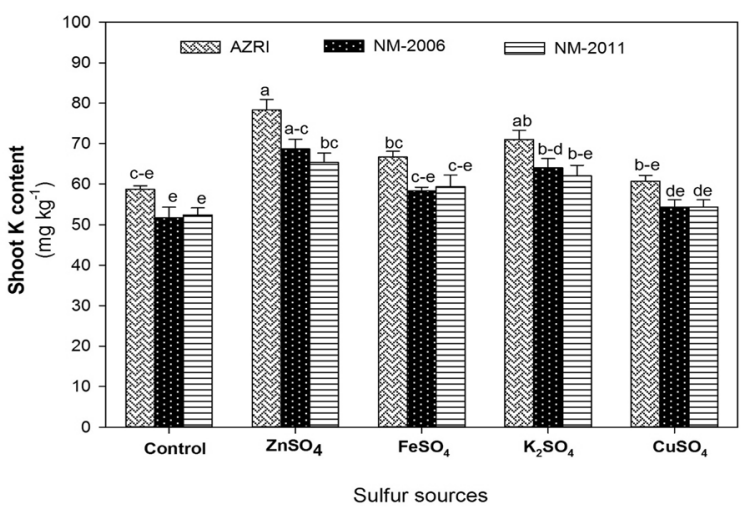

Fig. 2 Effect of different $\mathrm{S}$-sources viz. no $\mathrm{S}$ supply (control), $\mathrm{ZnSO}_{4}, \mathrm{FeSO}_{4}, \mathrm{~K}_{2} \mathrm{SO}_{4}$ and $\mathrm{CuSO}_{4}$ on shoot a nitrogen, b phosphorous and $\mathbf{c}$ potassium content of three mung bean cultivars (NM-2006, NM-2011 and AZRI-2006). Treatment means that are significantly different are represented by different letters, after applying post-hoc Tukey's HSD test

\section{Leaf RWC and SPAD value}

Drought stress considerably decreased $(P \leq 0.01)$ the leaf RWC of mung bean plants (Suppl. Table 2). Under wellwatered and drought conditions, the combined application of $\mathrm{S}$ and $\mathrm{Se}\left(\mathrm{S}+\mathrm{Se}_{2}\right)$ resulted in maximum leaf RWC and improved it by 10 and $16 \%$ in normal and water-stressed plants, respectively compared to control. Individual application of $\mathrm{ZnSO}_{4}(\mathrm{~S})$ and low $\left(\mathrm{Se}_{1}\right)$ or high Se dose $\left(\mathrm{Se}_{2}\right)$ also improved leaf RWC by 9 and $12 \%$, respectively under drought stress conditions (Fig. 3a).

The exposure to drought showed a marked reduction (32\%) in leaf Chl content (measured as a SPAD value) of mung bean plants $(P \leq 0.01$, Suppl. Table 2$)$. Under wellwatered conditions, no significant effect of individual or combined $\mathrm{S}$ and Se doses was observed on this variable, whereas $\mathrm{S}+\mathrm{Se}_{1}$ markedly enhanced leaf $\mathrm{Chl}(72 \%)$ under drought stress conditions (Fig. 3b). The leaf Chl were also increased by individual Se application as low $\left(\mathrm{Se}_{1}\right)$ or high Se dose $\left(\mathrm{Se}_{2}\right)$ improved SPAD value by 38 and $34 \%$, respectively while $\mathrm{ZnSO}_{4}$ supply alone (S) did not affect leaf $\mathrm{Chl}$ compared to control under water deficit conditions (Fig. 3b).

\section{Gas exchange}

A significant variation $(P \leq 0.01)$ existed among individual or combined treatment of $\mathrm{S}$ and $\mathrm{Se}$ for leaf gas exchange attributes under well-watered and drought stress conditions (Suppl. Table 2). Under well-watered conditions, the highest increase (32\%) in leaf $A$ was observed in plants treated with $\mathrm{S}$ in combination with $2 \mu \mathrm{mol} \mathrm{Se} \mathrm{\textrm {L } ^ { - 1 }}$ i.e. $\mathrm{S}+\mathrm{Se}_{1}$ however, it resulted in a much higher increase (80\%) in leaf $A$ statistically related to $\mathrm{S}+\mathrm{Se}_{2}(120 \mathrm{mg} \mathrm{S}$ pot $^{-1}+4 \mu \mathrm{mol} \mathrm{Se} \mathrm{L}^{-1}$ ) compared to control (no $\mathrm{S}$ and/or Se application) under drought stress (Table 2). In the plants exposed to drought stress, leaf $g_{s}$ and $C_{i}$ were increased by 87 and $92 \%$, respectively by $\mathrm{S}+\mathrm{Se}_{2}$ application, in contrast to 62 and $23 \%$ increase in these variables compared to control under normal conditions (Table 2). Similarly, the highest leaf $E$ was also maintained by the plants treated with combined $\mathrm{S}+\mathrm{Se}_{2}$ application (88\%) statistically at par with $\mathrm{S}+\mathrm{Se}_{1}(85 \%)$ with respect to control under drought stress conditions (Table 2).

\section{Enzyme antioxidants}

Drought stress markedly enhanced the activities of enzyme antioxidants viz. CAT, GPX, and SOD in the leaves of mung bean plants, irrespective of $\mathrm{S}$ and Se treatments (Suppl. Table 2). The highest increase in activity of antioxidative enzymes was recorded in the combination of $\mathrm{S}$ and $\mathrm{Se}$ treatments i.e. $\mathrm{S}+\mathrm{Se}_{1}$ and $\mathrm{S}+\mathrm{Se}_{2}$ (Fig. 4). 
Table 2 The net photosynthetic rate $(A)$, transpiration rate $(E)$, stomatal conductance $\left(g_{s}\right)$ and sub-stomatal conductance $\left(C_{i}\right)$ of mung bean plants under well watered and drought stress conditions. The

\begin{tabular}{|c|c|c|c|c|}
\hline Treatments & $\begin{array}{l}A \\
\left(\mu \mathrm{mol} \mathrm{CO} \mathrm{C}^{-2} \mathrm{~s}^{-1}\right)\end{array}$ & $\begin{array}{l}E \\
\left(\mathrm{mmol} \mathrm{H} \mathrm{H}_{2} \mathrm{~m}^{-2} \mathrm{~s}^{-1}\right)\end{array}$ & $\begin{array}{l}g_{s} \\
\left(\mathrm{mmol} \mathrm{H} \mathrm{H}_{2} \mathrm{~m}^{-2} \mathrm{~s}^{-1}\right)\end{array}$ & $\begin{array}{l}C_{i} \\
\left(\mathrm{mmol} \mathrm{H}_{2} \mathrm{O} \mathrm{m}^{-2} \mathrm{~s}^{-1}\right)\end{array}$ \\
\hline \multicolumn{5}{|l|}{ Well watered } \\
\hline Control & $5.90^{\mathrm{b}}$ & $3.26^{\mathrm{d}}$ & $38.33^{\mathrm{bc}}$ & $133.67^{b-d}$ \\
\hline S & $6.0^{\mathrm{ab}}$ & $3.73^{\mathrm{bc}}$ & $46.67^{\mathrm{ab}}$ & $151.0^{\mathrm{a}-\mathrm{c}}$ \\
\hline $\mathrm{Se}_{1}$ & $5.87^{\mathrm{ab}}$ & $3.46^{\mathrm{cd}}$ & $47.0^{\mathrm{ab}}$ & $152.33^{\mathrm{a}-\mathrm{c}}$ \\
\hline $\mathrm{Se}_{2}$ & $6.83^{\mathrm{ab}}$ & $3.65^{\mathrm{cd}}$ & $51.67^{\mathrm{ab}}$ & $166.0^{\mathrm{a}}$ \\
\hline $\mathrm{S}+\mathrm{Se}_{1}$ & $7.0^{\mathrm{a}}$ & $4.15^{\mathrm{a}}$ & $51.33^{\mathrm{ab}}$ & $157.0^{\mathrm{a}-\mathrm{c}}$ \\
\hline $\mathrm{S}+\mathrm{Se}_{2}$ & $6.77^{\mathrm{ab}}$ & $4.14^{\mathrm{ab}}$ & $58.0^{\mathrm{a}}$ & $159.67^{\mathrm{ab}}$ \\
\hline \multicolumn{5}{|l|}{ Drought stress } \\
\hline Control & $3.43^{\mathrm{d}}$ & $0.87^{\mathrm{g}}$ & $13.67^{\mathrm{e}}$ & $61.67^{\mathrm{g}}$ \\
\hline S & $4.47^{\mathrm{cd}}$ & $1.09^{\mathrm{fg}}$ & $17.0^{\mathrm{de}}$ & $81.33^{\mathrm{fg}}$ \\
\hline $\mathrm{Se}_{1}$ & $4.0^{\mathrm{cd}}$ & $1.01^{\mathrm{g}}$ & $19.0^{\mathrm{de}}$ & $76.0^{\mathrm{fg}}$ \\
\hline $\mathrm{Se}_{2}$ & $4.37^{\mathrm{cd}}$ & $1.45^{\mathrm{ef}}$ & $27.67^{\mathrm{c}-\mathrm{e}}$ & $94.0^{\mathrm{ef}}$ \\
\hline $\mathrm{S}+\mathrm{Se}_{1}$ & $4.60^{c}$ & $1.60^{\mathrm{e}}$ & $25.0^{\mathrm{c}-\mathrm{e}}$ & $114.33^{\mathrm{de}}$ \\
\hline $\mathrm{S}+\mathrm{Se}_{2}$ & $4.80^{\mathrm{c}}$ & $1.65^{\mathrm{e}}$ & $29.33^{\mathrm{cd}}$ & $125.67^{\mathrm{cd}}$ \\
\hline Tukey $\mathrm{HSD}_{0.05}$ & 1.06 & 0.41 & 14.31 & 31.64 \\
\hline $\mathrm{CV}$ & 6.73 & 5.56 & 13.63 & 8.69 \\
\hline
\end{tabular}

values indicate the treatment means of three replicates. The means with same alphabets exhibit no significant difference
Mung bean plants treated with $\mathrm{S}+\mathrm{Se}_{2}$ exhibited the highest CAT $(79 \%)$ and GPX (53\%) activity statistically related to $\mathrm{S}+\mathrm{Se}_{1}$ treatment with respect to control under drought stress. Among individual treatments, foliar spray of high Se dose $\left(\mathrm{Se}_{2}\right)$ also stimulated CAT (28\%) and GPX $(37 \%)$ activities, whereas low Se dose $\left(\mathrm{Se}_{1}\right)$ or $\mathrm{S}$ application enhanced CAT activity by 17 and $26 \%$ (Fig. 4a) and GPX activity by $19 \%$ (Fig. 4b) compared to control under water deficit conditions. The highest increase in SOD activity $(81 \%)$ was also recorded in water-stressed mung bean plants applied with combined $\mathrm{S}+\mathrm{Se}_{2}$ treatment (Fig. 4c). No significant variation for SOD activity was recorded between $\mathrm{S}+\mathrm{Se}_{1}$ and $\mathrm{Se}_{2}$ treatments that stimulated enzyme activity by $58 \%$, whereas $\mathrm{Se}_{1}$ and $\mathrm{S}$ did not considerably affect SOD activity with respect to control under water deficit conditions.

\section{Yield attributes}

Drought stress, in relation to well-watered conditions, caused a marked reduction in mung bean yield $(P \leq 0.01$, Suppl. Table 3). Mung bean plants treated with $\mathrm{S}$ and $\mathrm{Se}$ in combination $\left(\mathrm{S}+\mathrm{Se}_{1}, \mathrm{~S}+\mathrm{Se}_{2}\right)$ showed marked improvement in GW, GY and BY under both well-watered and drought stress conditions. In comparison to no $\mathrm{S}$ or $\mathrm{Se}$ application (control), combined $\mathrm{S}+\mathrm{Se}_{2}$ application resulted in the highest increase in GW (11\%), GY (105\%), and $\mathrm{BY}(75 \%)$ followed by $\mathrm{S}+\mathrm{Se}_{1}$ treatment that improved GW, GY, and BY by 7, 68 and $48 \%$, respectively under water deficit conditions, whereas no significant differences were obtained when $\mathrm{S}$ or $\mathrm{Se}$ was applied as individual treatments (Fig. 5).

\section{Seed mineral content}

Under drought stress, the nutrient content (N, P, K, Zn, S, and $\mathrm{Fe}$ ) in seeds of mung bean plants was considerably decreased (Suppl. Table 3). Particularly, seed K content was decreased by $48 \%$, whereas $\mathrm{P}, \mathrm{Zn}$, and $\mathrm{S}$ concentrations in seeds were reduced by 65,68 and $96 \%$, respectively compared to seeds of plants grown under wellwatered conditions (Table 3). Seeds from mung bean plants grown with $\mathrm{S}, \mathrm{Se}$ or $\mathrm{S}+\mathrm{Se}$ showed considerable enhancement in mineral content. As compared to no $\mathrm{S}$ or Se supply (control), the highest increase in seed concentrations of $\mathrm{P}(47 \%)$ and $\mathrm{K}(75 \%)$ was recorded by $\mathrm{S}+\mathrm{Se}_{1}$ (Table 3), whereas $\mathrm{S}+\mathrm{Se}_{2}$ resulted in the maximum seed $\mathrm{N}$ content (12\%) closely followed by $\mathrm{Se}_{2}(11 \%)$ and $\mathrm{S}+\mathrm{Se}_{1}(10 \%)$ under drought stress conditions (Table 3). Although differences in $\mathrm{S}$ and $\mathrm{Zn}$ seed concentrations between the individual or combined $\mathrm{S}$ or $\mathrm{Se}$ treatments were not significant under well-watered conditions, a marked enhancement in seed $\mathrm{S}(80 \%)$ and $\mathrm{Zn}(160 \%)$ content was recorded by $\mathrm{S}+\mathrm{Se}_{1}$ treatment compared to control under water deficit conditions (Table 3). Similarly, $\mathrm{S}+\mathrm{Se}_{2}$ and $\mathrm{Se}_{2}$ improved $\mathrm{Zn}$ seed concentrations by 125 
a.

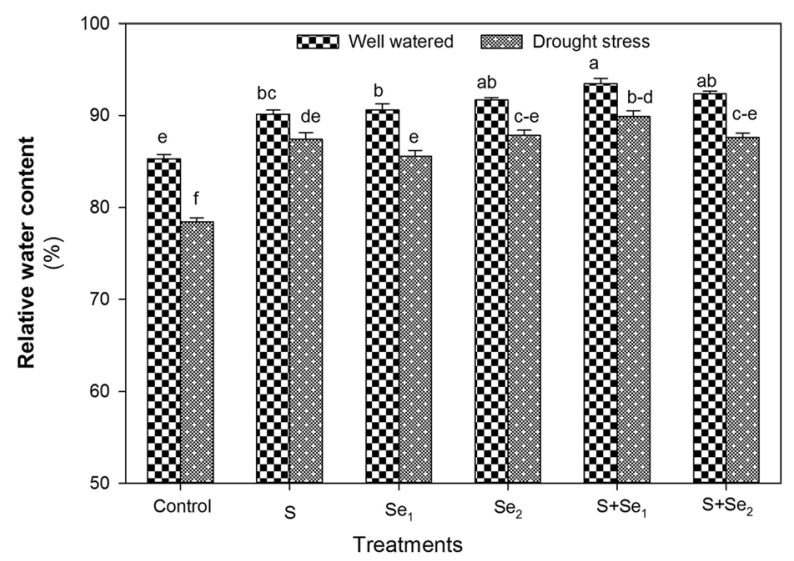

b.

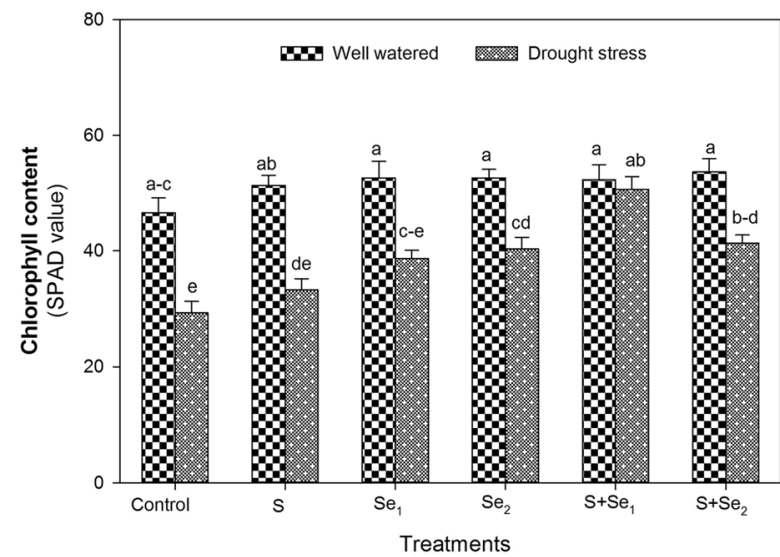

Fig. 3 The individual and combined effect of $\mathrm{S}\left(\mathrm{ZnSO}_{4}\right)$ and $\mathrm{Se}$ $\left(\mathrm{Na}_{2} \mathrm{SeO}_{4}\right)$ on a leaf relative water content and $\mathbf{b}$ total chlorophyll content of mung bean plants under well-watered and drought stress conditions. $S_{1}=120 \mathrm{mg} S$ pot $^{-1}, \mathrm{Se}_{1}=2 \mu \mathrm{mol} \mathrm{Se} \mathrm{L} \mathrm{L}^{-1}, \mathrm{Se}_{2}$ $=4 \mu \mathrm{mol} \mathrm{Se} \mathrm{L}{ }^{-1}, \mathrm{~S}+\mathrm{Se}_{1}=120 \mathrm{mg} \mathrm{S}$ pot $^{-1}+2 \mu \mathrm{mol} \mathrm{Se} \mathrm{L^{-1 }}$ and $\mathrm{S}+\mathrm{Se}_{2}=120 \mathrm{mg} \mathrm{S} \operatorname{pot}^{-1}+4 \mu \mathrm{mol} \mathrm{Se} \mathrm{L}^{-1}$. The significant differences among treatment means are represented by different letters, after applying post-hoc Tukey's HSD test

and $67 \%$, respectively while no application (control) gave the lowest values for $\mathrm{Zn}$ seed concentrations followed by individual $\mathrm{S}$ or low Se supply $\left(\mathrm{Se}_{1}\right)$ treatments in waterstressed mung bean plants (Table 3). Under well-watered conditions, seed $\mathrm{Fe}$ and $\mathrm{Mn}$ concentrations were significantly increased by 15 and $26 \%$, respectively in plants treated with combined $\mathrm{S}$ and $\mathrm{Se}$ applications i.e. $\mathrm{S}+\mathrm{Se}_{1}$ and $\mathrm{S}+\mathrm{Se}_{2}$ compared to control. A similar trend was noted in water-stressed plants as $\mathrm{S}+\mathrm{Se}_{2}$ resulted in the highest (15\%) seed Fe content (Table 3), however, a much higher increase of $37 \%$ was noted for Mn concentration by this treatment compared to control (Table 3). In contrast, individual $\mathrm{S}$ and Se doses were found statistically similar to control regarding seed $\mathrm{Fe}$ and $\mathrm{Mn}$ content. a.

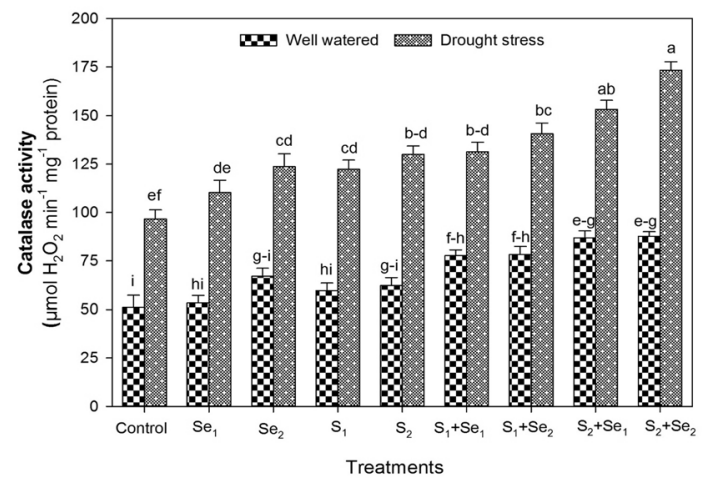

b.

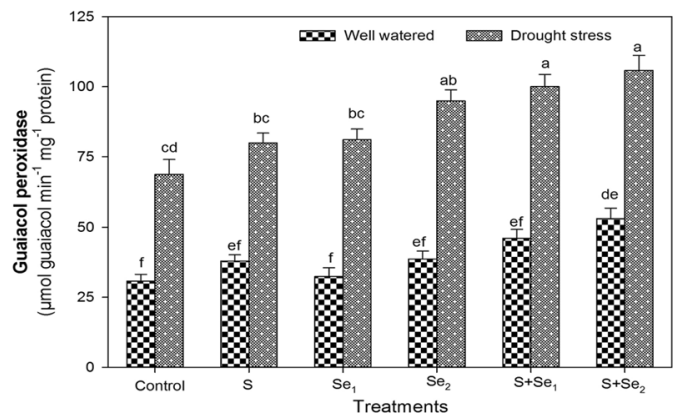

c.

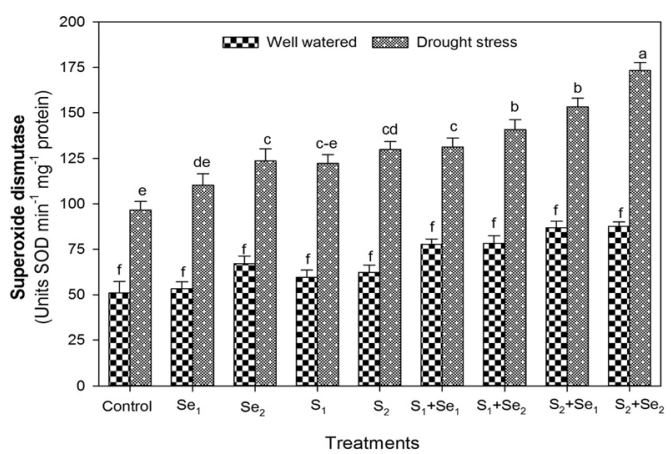

Fig. 4 The individual and combined effect of $\mathrm{S}\left(\mathrm{ZnSO}_{4}\right)$ and $\mathrm{Se}$ $\left(\mathrm{Na}_{2} \mathrm{SeO}_{4}\right)$ on enzyme activity of $\mathbf{a}$ catalase $\mathbf{b}$ guaiacol peroxidase and c superoxide dismutase in leaves of mung bean plants under wellwatered and drought stress conditions. $S_{1}=120 \mathrm{mg} \mathrm{S}$ pot $^{-1}$, $\mathrm{Se}_{1}=2 \mu \mathrm{mol} \mathrm{Se} \mathrm{L}{ }^{-1}, \mathrm{Se}_{2}=4 \mu \mathrm{mol} \mathrm{Se} \mathrm{L}{ }^{-1}, \mathrm{~S}+\mathrm{Se}_{1}=120 \mathrm{mg} \mathrm{S}$ pot $^{-1}+2 \mu \mathrm{mol} \mathrm{Se} \mathrm{L}{ }^{-1}$ and $\mathrm{S}+\mathrm{Se}_{2}=120 \mathrm{mg} \mathrm{S} \mathrm{pot}{ }^{-1}+4 \mu \mathrm{mol}$ $\mathrm{Se} \mathrm{L}^{-1}$. The significant differences among treatment means are represented by different letters, after applying post-hoc Tukey's HSD test

\section{Discussion}

Most agricultural soils lack S and contain less than $10 \%$ of the total soil $\mathrm{S}$ in the plant available form i.e. $\mathrm{SO}_{4}$ (Urton et al. 2018). Consequently, the organic S sources (soil organic matter and crop residues) are primary $\mathrm{SO}_{4}$ sources for plants during the growth season (Havlin et al. 2014). The increase in biomass of mung bean cultivars in response 
Table 3 The concentrations of nitrogen $(\mathrm{N})$, phosphorous $(\mathrm{P})$, potassium $(\mathrm{K})$, zinc $(\mathrm{Zn})$, sulfur $(\mathrm{S})$, iron $(\mathrm{Fe})$ and manganese $(\mathrm{Mn})$ in the seeds of mung bean plants at maturity under well watered and

\begin{tabular}{|c|c|c|c|c|c|c|c|}
\hline Treatments & $\begin{array}{l}\mathrm{N} \\
\left(\mu \mathrm{g} \mathrm{g}^{-1} \mathrm{DW}\right)\end{array}$ & $\begin{array}{l}\mathrm{P} \\
\left(\mu \mathrm{g} \mathrm{g}^{-1} \mathrm{DW}\right)\end{array}$ & $\begin{array}{l}\mathrm{K} \\
\left(\mu \mathrm{g} \mathrm{g}^{-1} \mathrm{DW}\right)\end{array}$ & $\begin{array}{l}\mathrm{Zn} \\
\left(\mu \mathrm{g} \mathrm{g}^{-1} \mathrm{DW}\right)\end{array}$ & $\begin{array}{l}\mathrm{S} \\
\left(\mu \mathrm{g} \mathrm{g}^{-1} \mathrm{DW}\right)\end{array}$ & $\begin{array}{l}\mathrm{Fe} \\
\left(\mu \mathrm{g} \mathrm{g}^{-1} \mathrm{DW}\right)\end{array}$ & $\begin{array}{l}\mathrm{Mn} \\
\left(\mu \mathrm{g} \mathrm{g}^{-1} \mathrm{DW}\right)\end{array}$ \\
\hline \multicolumn{8}{|l|}{ Well watered } \\
\hline Control & $1.21^{\mathrm{de}}$ & $0.60^{\mathrm{a}}$ & $5.87^{\mathrm{a}}$ & $29.87^{\mathrm{a}}$ & $0.38^{\mathrm{ab}}$ & $61.90^{\mathrm{a}-\mathrm{c}}$ & $15.87^{\mathrm{ab}}$ \\
\hline S & $1.31^{\mathrm{a}-\mathrm{e}}$ & $0.65^{\mathrm{a}}$ & $6.43^{\mathrm{a}}$ & $34.73^{\mathrm{a}}$ & $0.44^{\mathrm{a}}$ & $70.23^{\mathrm{ab}}$ & $17.40^{\mathrm{ab}}$ \\
\hline $\mathrm{Se}_{1}$ & $1.27^{\mathrm{b}-\mathrm{e}}$ & $0.63^{\mathrm{a}}$ & $6.33^{\mathrm{a}}$ & $34.37^{\mathrm{a}}$ & $0.42^{\mathrm{ab}}$ & $64.97^{\mathrm{a}-\mathrm{c}}$ & $17.90^{\mathrm{ab}}$ \\
\hline $\mathrm{Se}_{2}$ & $1.38^{\mathrm{ab}}$ & $0.63^{\mathrm{a}}$ & $6.47^{\mathrm{a}}$ & $35.23^{\mathrm{a}}$ & $0.43^{\mathrm{ab}}$ & $66.43^{\mathrm{a}-\mathrm{c}}$ & $15.23^{\mathrm{ab}}$ \\
\hline $\mathrm{S}+\mathrm{Se}_{1}$ & $1.33^{\mathrm{a}-\mathrm{d}}$ & $0.66^{\mathrm{a}}$ & $6.57^{\mathrm{a}}$ & $33.20^{\mathrm{a}}$ & $0.45^{\mathrm{a}}$ & $71.07^{\mathrm{a}}$ & $20.20^{\mathrm{a}}$ \\
\hline $\mathrm{S}+\mathrm{Se}_{2}$ & $1.40^{\mathrm{a}}$ & $0.63^{\mathrm{a}}$ & $6.63^{\mathrm{a}}$ & $35.83^{\mathrm{a}}$ & $0.46^{\mathrm{a}}$ & $71.30^{\mathrm{a}}$ & $18.73^{\mathrm{ab}}$ \\
\hline \multicolumn{8}{|l|}{ Drought stress } \\
\hline Control & $1.20^{\mathrm{e}}$ & $0.32^{\mathrm{c}}$ & $3.03^{\mathrm{e}}$ & $11.77^{\mathrm{c}}$ & $0.17^{\mathrm{d}}$ & $57.83^{\mathrm{c}}$ & $12.90^{\mathrm{b}}$ \\
\hline S & $1.28^{\mathrm{a}-\mathrm{e}}$ & $0.39^{\mathrm{bc}}$ & $3.73^{\mathrm{de}}$ & $15.56^{\mathrm{c}}$ & $0.22^{\mathrm{cd}}$ & $61.50^{\mathrm{a}-\mathrm{c}}$ & $17.17^{\mathrm{ab}}$ \\
\hline $\mathrm{Se}_{1}$ & $1.24^{\mathrm{c}-\mathrm{e}}$ & $0.34^{\mathrm{c}}$ & $4.77^{\mathrm{c}}$ & $18.11^{\mathrm{c}}$ & $0.20^{\mathrm{cd}}$ & $58.40^{\mathrm{bc}}$ & $15.13^{\mathrm{ab}}$ \\
\hline $\mathrm{Se}_{2}$ & $1.33^{\mathrm{a}-\mathrm{d}}$ & $0.39^{\mathrm{bc}}$ & $4.57^{\mathrm{cd}}$ & $19.63^{\mathrm{bc}}$ & $0.16^{\mathrm{d}}$ & $58.18^{\mathrm{bc}}$ & $15.23^{\mathrm{ab}}$ \\
\hline $\mathrm{S}+\mathrm{Se}_{1}$ & $1.31^{\mathrm{a}-\mathrm{e}}$ & $0.47^{\mathrm{b}}$ & $5.30^{\mathrm{bc}}$ & $30.67^{\mathrm{a}}$ & $0.31^{\mathrm{bc}}$ & $62.43^{\mathrm{a}-\mathrm{c}}$ & $15.43^{\mathrm{ab}}$ \\
\hline $\mathrm{S}+\mathrm{Se}_{2}$ & $1.34^{\mathrm{a}-\mathrm{c}}$ & $0.38^{\mathrm{b}}$ & $4.40^{\mathrm{cd}}$ & $27.71^{\mathrm{ab}}$ & $0.24^{\mathrm{cd}}$ & $66.60^{\mathrm{a}-\mathrm{c}}$ & $17.73^{\mathrm{ab}}$ \\
\hline Tukey $\mathrm{HSD}_{0.05}$ & 0.13 & 0.11 & 0.98 & 8.17 & 0.12 & 12.11 & 6.07 \\
\hline $\mathrm{CV}$ & 3.27 & 7.35 & 6.16 & 10.11 & 12.83 & 6.35 & 12.34 \\
\hline
\end{tabular}

drought stress conditions. The values indicate the treatment means of three replicates. The means with same alphabets exhibit no significant difference to different $\mathrm{S}$ fertilizers compared to control (no $\mathrm{S}$ supply) is consistent with the availability of low $\mathrm{SO}_{4}$ levels in soil used for these experiments. A marked improvement in biomass was noted by $\mathrm{S}$ fertilizer amendments, which may be due to the positive effects of $S$ on cell division resulting in leaf expansion and light absorption that ultimately improved the vegetative growth (Garg et al. 2006). A highly significant increase in SL was noted in plants supplemented with various $\mathrm{SO}_{4}$ fertilizers except $\mathrm{CuSO}_{4}$ (Fig. 1a). Similarly, a considerable increase in RL and dry matter content was also observed in mung bean plants treated with $\mathrm{S}$ fertilizers (Fig. 1). Availability of $\mathrm{SO}_{4}$ in growth medium is positively correlated to indole-3-acetic acid (IAA) levels in root meristem that promotes primary root elongation to facilitate the uptake of nutrients and moisture (Zhao et al. 2014). A positive effect of S fertilizers on the dry matter of mung bean plants might be due to increased carbohydrate utilization for protein synthesis in the presence of S (Shekhawat and Shivay 2012). These results are in line with studies on wheat (Salvagiotti and Miralles 2008) and barley (De Bona et al. 2011) grown on $\mathrm{SO}_{4}$ deficient soils. Among various $\mathrm{S}$ fertilizers, the maximum biomass was attained in plants fertilized with $\mathrm{ZnSO}_{4}$. It might be attributed to regulatory functions of both $\mathrm{Zn}^{2+}$ and $\mathrm{SO}_{4}{ }^{2-}$ to stimulate the activity of enzymes such as aldolases, hydrogenases, nucleic acid polymerases. Moreover, they also act as a cofactor to regulate protein synthesis thereby contributing to increased biomass in plants
(Rossi et al. 2018). The possible explanation for the decrease in biomass by $\mathrm{CuSO}_{4}$ application may be the presence of $\mathrm{Cu}^{2+}$ that alters root morphology to decrease xylem loading of water and nutrients in plants (Chen et al. 2015).

The metabolism of $\mathrm{N}$ in plants is strongly affected by the S status of the plant (Anjum et al. 2012). It was observed that NPK uptake was considerably higher in AZRI-2006 compared to NM-2006 and NM-2011 (Fig. 2). These results suggest that AZRI-2006 has a high capacity to uptake NPK and can respond better to $\mathrm{SO}_{4}{ }^{2-}$ availability. Our results are in agreement with reports of Lee et al. (2015) who observed significant variation among Brassica species in their response to $\mathrm{S}$ nutrition. Among S-fertilizers, $\mathrm{ZnSO}_{4}$ and $\mathrm{FeSO}_{4}$ markedly improved $\mathrm{N}$ uptake in mung bean plants (Fig. 2a). The increased $\mathrm{N}$ content by $\mathrm{ZnSO}_{4}$ might be related to increased activity of $\mathrm{SO}_{4}{ }^{2-}$ transporters in the root with $\mathrm{Zn}^{2+}$ exposure resulting in enhanced $\mathrm{NO}_{3}{ }^{-}$absorption and translocation in leaves (Stuiver et al. 2014). Plants have well-developed S and N pathways, which are functionally convergent as the availability of one nutrient regulates the other (Kaur et al. 2013). A marked increment in $\mathrm{P}$ uptake was observed in plants treated with S-fertilizers. Taalab et al. (2008) reported that combined application of different $\mathrm{P}$ sources with $\mathrm{S}$ results in better uptake of macronutrients such as $\mathrm{N}, \mathrm{P}$, and $\mathrm{K}$ compared to $\mathrm{P}$ alone. Likewise, S-application enhanced $\mathrm{K}$ content in the shoot, which might be associated with the 
a.

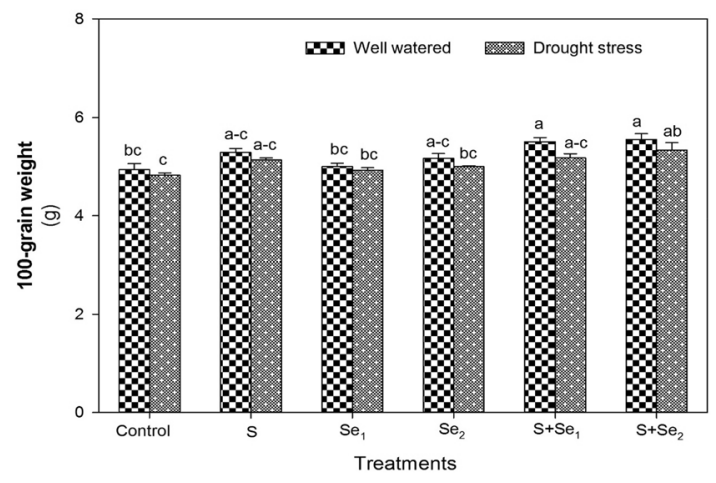

b.

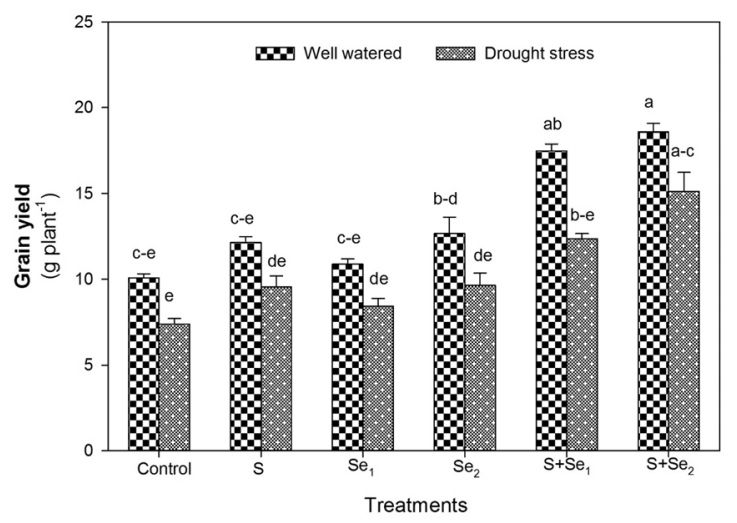

c.

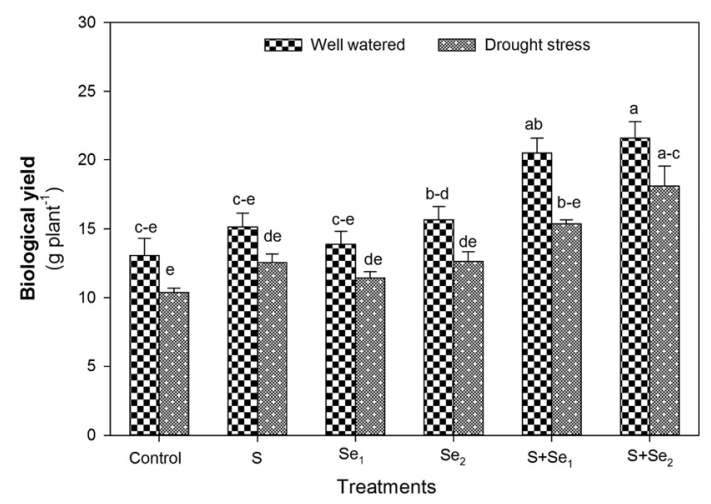

Fig. 5 The individual and combined effect of $\mathrm{S}\left(\mathrm{ZnSO}_{4}\right)$ and Se $\left(\mathrm{Na}_{2} \mathrm{SeO}_{4}\right)$ on a 100-grain weight $\mathbf{b}$ grain yield and $\mathbf{c}$ biological yield of mung bean plants under well-watered and drought stress conditions. $\mathrm{S}_{1}=120 \mathrm{mg} \mathrm{S}$ pot $^{-1}, \mathrm{Se}_{1}=2 \mu \mathrm{mol} \mathrm{Se} \mathrm{L}{ }^{-1}, \mathrm{Se}_{2}=4 \mu \mathrm{mol} \mathrm{Se}$ $\mathrm{L}^{-1}, \mathrm{~S}+\mathrm{Se}_{1}=120 \mathrm{mg} \mathrm{S}$ pot $^{-1}+2 \mu \mathrm{mol} \mathrm{Se} \mathrm{L}^{-1}$ and $\mathrm{S}+\mathrm{Se}_{2}$

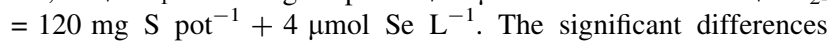
among treatment means are represented by different letters, after applying post-hoc Tukey's HSD test

fact that S and K act as counter-ions (Bäucker et al. 2003). Chinese cabbage plants exposed to $\mathrm{S}$ deficiency were observed to accumulate fewer $\mathrm{K}^{+}$in the shoot by Reich et al. (2016). Increased NPK accumulation in mung bean leaves by $\mathrm{FeSO}_{4}$ application provides further evidence regarding the cooperative effect of $\mathrm{Fe}-\mathrm{S}$ clusters on plant metabolism ( $\mathrm{Lu}$ 2018). In contrast, $\mathrm{Cu}^{2+}$ exposure in the root zone markedly decreases the uptake and distribution of $\mathrm{SO}_{4}{ }^{2-}$ (Shahbaz et al. 2014) that also reduces NPK uptake due to the limited incorporation of proteins in leaves.

Mung bean is considered a drought-tolerant crop, however; water deficiency at critical growth stages may result in significant yield losses (Singh and Singh 2011). Application of $\mathrm{S}$ has been observed as increasing the resistance of plants under drought stress as it helps to regulate metabolic processes and is the main constituent of metabolites involved in protein synthesis under waterlimited conditions (Vazin 2012). Foliar treatment of mung bean plants with $\mathrm{Se}$ in combination with $\mathrm{S}(\mathrm{S}+\mathrm{Se})$ considerably improved RWC (Fig. 2a), which signifies synergistic relation of these nutrients in the accumulation of solutes to sustain water status under drought (Hartikainen 2005). Se increases water retention in the plant tissues through improved uptake of water by the root system (Nawaz et al. 2015a). The regulation of stomatal apparatus with $\mathrm{S}+\mathrm{Se}$ supply (as observed in the present study, Table 2) might be responsible for improved leaf RWC under water stress conditions (Usmani et al. 2020). The hydraulic conductance of plant species is a major function for increased water status under stress conditions (Schultz 2003) hence, an increase in RWC of plants treated with $\mathrm{S}+\mathrm{Se}$ indicates the positive role of these nutrients in increasing water uptake by roots without decreasing $E$ under water deficit conditions. S availability helps to maintain osmotic potential by restricting the cellular accumulation of ions and solutes (Lee et al. 2015). Similarly, Se helps to maintain membrane integrity (Chauhan et al. 2019) or reduces oxidative damage (Shekari et al. 2019). Photosynthetic pigments like chlorophyll indicate the photosynthetic capacity of plants (Chutipaijit et al. 2011). It is well reported that exogenous $\mathrm{S}$ or Se supply prevents the damage to chloroplasts and increases the pigments under drought stress conditions (Usmani et al. 2020). A marked increase in SPAD value (an indicator of total leaf Chl) was noted with $\mathrm{S}+$ Se supply which might be associated with sulphurs' role in the maintenance of chloroplast targeted proteins (cysteine and methionine) as well as Se mediated scavenging of ROS through increased activity of antioxidants (also observed in the present study) to inhibit lipid peroxidation that leads to chlorophyll destruction (Habibi 2013).

As expected, low water availability markedly reduced $A$, $E$, $g_{s}$, and $C_{i}$ in leaves of mung bean plants. The reduction in $A$ result from decreased $g_{s}$ that restricts $\mathrm{CO}_{2}$ assimilation and uptake of nutrients from the soil due to limited $E$. In this study, the application of $\mathrm{S}+\mathrm{Se}$ considerably improved $A$ (Table 2) suggesting these nutrients work 
synergistically to prevent Rubisco deactivation, chlorophyll degradation, and stomatal closure. This might also be attributed to the fact that both $\mathrm{S}$ and Se positively influence turgor maintenance, thereby increasing tolerance in a water-limited environment. S deficiency has been reported to severely restrict $A$ in Brassica napus (Muneer et al. 2014), Brassica juncea (Fatma et al. 2014), and Hordeum vulgare (Astolfi et al. 2012) indicating that $S$ is crucial to maintain $A$ in plants. $\mathrm{S}$ is a vital constituent of ferredoxin and lipids found in the chloroplast. Moreover, sulfur bonds $(-\mathrm{S}-\mathrm{S}-)$ are very crucial for maintaining protein structure and disulfide groups are constituents of active sites of many enzymes (Speiser et al. 2018). Application of Se and S increased the $A, E$, and $g_{s}$, however, maximum activity was observed at combined higher doses of Se and S. This may be due to the synergistic effects of $\mathrm{S}$ and Se as both these nutrients share a similar assimilation pathway (Sors et al. 2005). Se-mediated increase in $A, E$, and $g_{s}$ has also been reported by Nawaz et al. (2015a) in wheat and Proietti et al. (2013) in olive plants. Moreover, Djanaguiraman et al. (2010) showed that Se-spray elevated $A$ in sorghum that might be related to Se-mediated low ROS levels and enhanced antioxidant activities.

A marked increment in enzyme activities of antioxidants was recorded by the application of $\mathrm{S}$ and $\mathrm{Se}$ in waterstressed mung bean plants, which could be attributed to the protective role of these enzymes to detoxify the elevated $\mathrm{H}_{2} \mathrm{O}_{2}$ into water and oxygen (Anjum et al. 2012). Enhanced enzyme activity of antioxidants in mung bean supplemented with exogenous Se has also been reported earlier (Malik et al. 2012; Alam et al. 2019). A well-organized antioxidant system plays a critical role to scavenge ROS under environmental stress conditions (Karl et al. 2009). The observed increase in SOD activity of mung bean plants by combined application of $\mathrm{S}\left(120 \mathrm{mg} \mathrm{pot}^{-1}\right)$ and $\mathrm{Se}$ $\left(4 \mu \mathrm{mol} \mathrm{L}{ }^{-1}\right)$ under drought stress (Fig. $4 \mathrm{c}$ ) provides further evidence about the protective characteristics of $S$ and Se to attenuate damaging effects of ROS and regulate the osmotic status of plants (Hajiboland et al. 2015). Plants produce SOD as a primary defense enzyme to scavenge ROS produced under drought (Hussain et al. 2016). Turkan et al. (2005) reported higher activity of CAT in droughttolerant varieties of bean cultivars compared to sensitive ones. Plants supplemented with $\mathrm{S}+\mathrm{Se}$ showed higher GPX and CAT activity and increased tolerance to the water-limited conditions. Increased GPX activity by Se supplementation corresponds to the reports of Yao et al. (2012). It may be inferred that high GPX activity promotes lignin biosynthesis that contributes to enhanced cell wall rigidity and increased uptake of mineral nutrients, thereby regulating the defense mechanism of plants to scavenge $\mathrm{H}_{2} \mathrm{O}_{2}$ (Gill and Tuteja 2010; Majeed et al. 2020).
Drought-induced significant reduction in mung bean yield was recorded in the present study (Fig. 5). The reduction in yield mainly results from a decreased translocation of nutrients due to the short duration of seed filling induced by drought stress (Nair et al. 2019). Moreover, water deficiency at the flowering stage causes flower and pod abortion resulting in small-sized seeds (Fang et al. 2010). In the present study, a significant increase in GW was recorded with combined S and Se application. S-mediated enhancement in yield has been reported in crops such as chickpea (Abd Allah et al. 2015), maize (Usmani et al. 2020), wheat (Tabak et al. 2019), and mung bean (Sachan et al. 2019). It has been suggested that S supply in combination with Se increases nutrient uptake particularly $\mathrm{N}$ and its translocation for the incorporation of proteins in seeds (Becana et al. 2018). Moreover, S + Se regulated enhanced photosynthetic activity also positively influenced the GW. A marked increase in BY was recorded by combined $\mathrm{S}+\mathrm{Se}$ application (Fig. 5b). It is more likely the consequence of efficient translocation of assimilates resulting in increased dry matter thereby increasing BY under water-deficient conditions. The increase in GY by $\mathrm{S}+\mathrm{Se}$ could be ascribed to improved water status (Fig. 2a) and gas exchange characteristics (Table 2), thereby improving GY under water deficit conditions.

The concentrations of minerals in grains are regulated by direct uptake from soil and/or remobilization of nutrient reserves in tissues during grain filling (Kutman et al. 2011). Exposure to drought impairs root architecture resulting in reduced nutrient uptake and changes in quantity of nutrients accumulated during seed filling (Sehgal et al. 2018). In this study, fewer negative effects of drought were noted on the nutrient content of mung bean seeds obtained from plants treated with the combined application of $\mathrm{S}$ and $\mathrm{Se}$. Limited water availability restricts $\mathrm{SO}_{4}{ }^{2-}$ uptake and its translocation to leaves (Usmani et al. 2020). Moreover, it also reduces nitrogen use efficiency (NUE) due to decreased $\mathrm{NO}_{3}{ }^{-}$absorption under water deficit conditions (Lee et al. 2009). Drought stress decreases protein incorporation in leaves due to low $\mathrm{S}$ demand that significantly limits $\mathrm{SO}_{4}{ }^{2-}$ uptake in water-stressed plants (Anderson and Fitzgerald 2003). Previous studies showed marked increment in $\mathrm{S}$ accumulation by Se application in lettuce (Ramos et al. 2011) Arabidopsis (White et al. 2004) and Kale (Lefsrud et al. 2006). Similarly in the present study, NPK content in seeds was significantly enhanced by $\mathrm{S}+\mathrm{Se}$ application in water-stressed plants (Table 3). Foliar Se spray not only increased N, P, and K concentrations but also enhanced $\mathrm{Zn}, \mathrm{S}, \mathrm{Fe}$, and $\mathrm{Mn}$ content in mung bean seeds. Similarly, Reis et al. (2018) reported positive interaction between $\mathrm{Se}$ and $\mathrm{N}$ that significantly increased the quality of rice seeds. In contrast, a negative correlation was recorded between $\mathrm{Se}$ and $\mathrm{N}$ in barley (Ilbas 
et al. 2012), which may be due to application of high Se doses resulting in Se toxicity. Similar to our observations, Eich-Greatorex et al. (2010) observed high P uptake by Se application suggesting that $\mathrm{Se}$ interactions with phosphate are largely dependent on the source of Se as selenite uptake is not efficient in P-enriched medium (Dinh et al. 2019). Contrary to our earlier report about no significant effect of Se on K content of wheat seeds (Nawaz et al. 2015b), an increased $\mathrm{K}$ content was recorded in mung bean seeds with $\mathrm{S}+\mathrm{Se}$ treatment. Likewise, $\mathrm{S}$ content were also improved by combined $\mathrm{S}$ and Se application supporting the observations of Guerrero et al. (2014) who observed that selenate promotes translocation of $\mathrm{S}$ and noted increased shoot $\mathrm{S}$ content in wheat. There was an increase in seed $\mathrm{Zn}$ content by $\mathrm{S}+\mathrm{Se}$ application, which may likely be the consequence of the application of $\mathrm{ZnSO}_{4}$ as a source of $\mathrm{S}$. However, Se application combined with $\mathrm{S}$ resulted in high $\mathrm{Zn}$ content compared to individual treatment of $\mathrm{S}$ or $\mathrm{Se}$ (Table 3). These observations correspond to the reports of de Figueiredo (2017) who observed that common bean plants treated with Se or Zn maintained a constant level of these minerals during seed development. An increased seed $\mathrm{Fe}$ and $\mathrm{Mn}$ content by $\mathrm{S}+\mathrm{Se}$ application could partly be ascribed to positive interactions of Fe with $\mathrm{S}$ and $\mathrm{Se}$ that favors the formation of $\mathrm{Fe}-\mathrm{S}$ clusters in cells involved in the photosynthetic activity (Nazar et al. 2011) thereby, alleviating negative effects of drought stress on uptake and translocation of mineral nutrients.

\section{Conclusion}

In conclusion, the combined application of $\mathrm{S}$ and $\mathrm{Se}$ $(\mathrm{S}+\mathrm{Se})$ was observed to confer drought tolerance in mung bean, by alleviating the damage caused by drought stress and stimulating the physiological processes such as increased water status, chlorophyll content and photosynthetic activity. Moreover, the increased activity of antioxidative enzymes by $\mathrm{S}+\mathrm{Se}$ application mitigated water deficit stress and improved yield and mineral status of mung bean under drought. These results could benefit farmers to obtain high nutrient concentrations in mung bean seeds with a limited supply of water. Besides, these results may also be of great interest to researchers including plant breeders to identify candidate genes regulated by both $\mathrm{S}$ and $\mathrm{Se}$, which play an important role in improving the drought tolerance and controlling mineral accumulation in seeds.

Acknowledgements Financial support as a Georg Forster postdoctoral fellowship to Dr. Fahim Nawaz by Alexander von-Humboldt $(\mathrm{AvH})$ Foundation, Germany is gratefully acknowledged.
Funding Open Access funding enabled and organized by Projekt DEAL.

Open Access This article is licensed under a Creative Commons Attribution 4.0 International License, which permits use, sharing, adaptation, distribution and reproduction in any medium or format, as long as you give appropriate credit to the original author(s) and the source, provide a link to the Creative Commons licence, and indicate if changes were made. The images or other third party material in this article are included in the article's Creative Commons licence, unless indicated otherwise in a credit line to the material. If material is not included in the article's Creative Commons licence and your intended use is not permitted by statutory regulation or exceeds the permitted use, you will need to obtain permission directly from the copyright holder. To view a copy of this licence, visit http://creativecommons. org/licenses/by/4.0/.

\section{References}

Aebi H (1984) Catalase in vitro. Meth Enzymol 105:121-126

Afzal F, Khan T, Khan A, Khan S, Raza H, Ihsan A, Ahanger MA, Kazi AG (2015) Nutrient deficiencies under stress in legumes: an overview. In: Azooz MM, Ahmad P (eds) Legumes under environmental stress: yield, improvement and adaptations. Wiley, New York, pp 53-65

Alam MZ, McGee R, Hoque MA, Ahammed GJ, Carpenter-Boggs L (2019) Effect of Arbuscular Mycorrhizal Fungi, Selenium and Biochar on Photosynthetic Pigments and Antioxidant Enzyme Activity Under Arsenic Stress in Mung Bean (Vigna radiata). Front Physiol 10

Allah MMSA, Eldin MM, Selim SM (2015) Effect of nitrogen and sulfur on yield, yield components, some chemical composition and nutritional quality of canola plant grown in saline soil condition. Res J Pharm Biochem Sci 6:1055-1064

Anderson JW, Fitzgerald MA (2003) Sulphur distribution and redistribution. In: Abrol YP, Ahmad A (eds) Sulphur in plants. Kluwer, Dordrecht, pp 113-134

Anjum NA, Gill SS, Umar S, Ahmad I, Duarte AC, Pereira E (2012) Improving growth and productivity of Oleiferous Brassicas under changing environment: significance of nitrogen and sulphur nutrition, and underlying mechanisms. Sci World J. https://doi.org/10.1100/2012/657808

AOAC (Association of Official Analytical Chemists). (1984). OfficialMethods of Analysis(14th ed). VA, USA: Arlington

Astolfi S, Zuchi S, Neumann G, Cesco S, di Toppi L, Pinton R (2012) Response of barley plants to Fe deficiency and Cd contamination as affected by S starvation. J Exp Bot 633:1241-1250. https:// doi.org/10.1093/jxb/err344

Banerjee A, Roychoudhury A (2019) Role of selenium in plants against abiotic stresses: phenological and molecular aspects. In: Roychoudhury A, Tripathi D (eds) Molecular plant abiotic stress, Wiley, pp 123-133

Bäucker E, Köhler R, Matschullat J, Wienhaus O, Zimmermann F (2003) Sulphate and cation accumulation in mesophyll and endodermis vacuoles of spruce needles-effects on nutrient supply after $\mathrm{SO}_{2}$ fumigation. Trees 17:1-10. https://doi.org/10. 1007/s00468-002-0199-x

Becana M, Wienkoop S, Matamoros MA (2018) Sulfur transport and metabolism in legume root nodules. Front Plant Sci 9:1434

Bocchini M, D'Amato R, Ciancaleoni S, Fontanella MC, Palmerini CA, Beone GM, Onofri A, Negri V, Marconi G, Albertini E, Businelli D (2018) Soil selenium (Se) biofortification changes the physiological, biochemical and epigenetic responses to water 
stress in Zea mays L. by inducing a higher drought tolerance. Front Plant Sci 9:389

Chandra N, Pandey N (2016) Role of sulfur nutrition in plant and seed metabolism of Glycine max L. J Plant Nutr 39:1103-1111

Chauhan R, Awasthi S, Srivastava S, Dwivedi S, Pilon-Smits EA, Dhankher OP, Tripathi RD (2019) Understanding selenium metabolism in plants and its role as a beneficial element. Critic Rev Environ Sci Technol 49:1937-1958

Chen PS, Toribara TT, Warner H (1956) Microdetermination of phosphorus. Anal Chem 28:1756-1758

Chen J, Shafi M, Li S, Wang Y, Wu J, Ye Z, Peng D, Yan W, Liu D (2015) Copper induced oxidative stresses, antioxidant responses and phytoremediation potential of Moso bamboo (Phyllostachys pubescens). Sci Rep 5:13554

Chutipaijit S, Chaum S, Sompornpailin K (2011) High contents of proline and anthocyanin increase protective response to salinity in Oryza sativa L. spp. indica. Aus J Crop Sci 5: 1191

De Bona FD, Fedoseyenko D, von Wirén N, Monteiro FA (2011) Nitrogen utilization by sulfur-deficient barley plants depends on the nitrogen form. Environ Exp Bot 74:237-244

de Figueiredo MA, Boldrin PF, Hart JJ, de Andrade MJ, Guilherme LR, Glahn RP, Li L (2017) Zinc and selenium accumulation and their effect on iron bioavailability in common bean seeds. Plant Physiol Biochem 111:193-202

Dinh QT, Wang M, Tran TAT, Zhou F, Wang D, Zhai H, Peng Q, Xue M, Du Z, Bañuelos GS, Lin ZQ (2019) Bioavailability of selenium in soil-plant system and a regulatory approach. Critic Rev Environ Sci Technol 49:443-517

Djanaguiraman M, Prasad PVV, Seppanen M (2010) Selenium protects sorghum leaves from oxidative damage under high temperature stress by enhancing antioxidant defense system. Plant Physiol Biochem 48:999-1007

Eich-Greatorex S, Krogstad T, Sogn TA (2010) Effect of phosphorus status of the soil on selenium availability. J Plant Nutr Soil Sci 173:337-344

Ernst L, Goodger JQ, Alvarez S, Marsh EL, Berla B, Lockhart E, Jung J, Li P, Bohnert HJ, Schachtman DP (2010) Sulphate as a xylemborne chemical signal precedes the expression of ABA biosynthetic genes in maize roots. J Exp Bot 61:3395-3405

Fang X, Turner NC, Yan G, Li F, Siddique KHM (2010) Flower numbers, pod production, pollen viability, and pistil function are reduced and flower and pod abortion increased in chickpea (Cicer arietinum L.) under terminal drought. J Exp Bot 61:335-345. https://doi.org/10.1093/jxb/erp307

Fatma M, Asgher M, Masood A, Khan NA (2014) Excess sulfur supplementation improves photosynthesis and growth in mustard under salt stress through increased production of glutathione. Environ Exp Bot 107:55-63. https://doi.org/10.1080/15592324. 2014.1003751

Fatma M, Masood A, Per TS, Khan NA (2016) Nitric oxide alleviates salt stress inhibited photosynthetic performance by interacting with sulfur assimilation in mustard. Front Plant Sci 7:521

Garg BK, Burman U, Kathju S (2006) Influence of thiourea on photosynthesis, nitrogen metabolism and yield of clusterbean (Cyamopsis tetragonoloba (L.) Taub.) under rainfed conditions of Indian arid zone. Plant Growth Regul 48:237-245

Gaur PM, Jukanti AK, Samineni S, Chaturvedi SK, Basu PS, Babbar A, Jeyalakshmi V, Nayyar H, Devasirvatham V, Mallikarjuna N (2012) Climate change and heat stress tolerance in chickpea. In: Tuteja N, Gill SS (eds) Climate change and plant abiotic stress tolerance. Wiley Blackwell, Weinheim, Germany, pp 839-855

Gill SS, Tuteja N (2010) Reactive oxygen species and antioxidant machinery in abiotic stress tolerance in crop plants. Plant Physiol Biochem 48:909-930

Giriappa S (1988) Water use efficiency in agriculture. In: Oxford and IBH Publishing Co., New Delhi, pp 6
Golob A, Kavčič J, Stibilj V, Gaberščik A, Vogel-Mikuš K, Germ M (2017) The effect of selenium and UV radiation on leaf traits and biomass production in Triticum aestivum L. Ecotoxicol Environ Saf 136:142-149

Guerrero B, Llugany M, Palacios O, Valiente M (2014) Dual effects of different selenium species on wheat. Plant Physiol Biochem 83:300-307

Habibi G (2013) Effect of drought stress and selenium spraying on photosynthesis and antioxidant activity of spring barley/Ucinek susnega stresa in skropljenja $\mathrm{s}$ selenom na fotosintezo in antioksidativno aktivnost jarega jecmena. Acta Agric Slov $101: 31$

Hajiboland R, Sadeghzadeh N, Ebrahimi N, Sadeghzadeh B, Mohammadi SA (2015) Influence of selenium in droughtstressed wheat plants under greenhouse and field conditions. Acta Agri Slov 105:175-191

Hajiboland R, Rahmat S, Zeinalzadeh N, Farsad-Akhtar N, Hosseinpour-Feizi MA (2019) Senescence is delayed by selenium in oilseed rape plants. J Trace Elem Med Bio 55:96-106

Hartikainen H (2005) Biogeochemistry of selenium and its impact on food chain quality and human health. J Trace Elem Med Bio 18:309-318

Havlin JL, Tisdale SL, Nelson WL, Beaton JD (2014) In: Soil fertility and fertilizers, 8th ed, New Jersey, USA: Prentice Hall

Honsel A, Kojima M, Haas R, Frank W, Sakakibara H, Herschbach C, Rennenberg H (2012) Sulphur limitation and early sulphur deficiency responses in poplar: significance of gene expression, metabolites, and plant hormones. J Exp Bot 63:1873-1893

Hussain RA, Ahmad R, Nawaz F, Ashraf MY, Warraich EA (2016) Foliar NK application mitigates drought effects in sunflower (Helianthus annuus L.). Acta Physiol Plantar 38: 83

Ilbas AI, Yilmaz S, Akbulut M, Bogdevich O (2012) Uptake and distribution of selenium, nitrogen and sulfur in three barley cultivars subjected to selenium applications. J Plant Nutr $35: 442-452$

Jackson ML, Barak P (2005) Soil chemical analysis: advanced course. UW-Madison Libraries Parallel Press, Madison (WI)

Karl TR, Melillo JM, Peterson TC (2009) Global climate change impacts in the United States. Cambridge University Press, Cambridge

Karpiuk UV, Al Azzam KM, Abudayeh ZH, Kislichenko V, Naddaf A, Cholak I, Yemelianova O (2016) Qualitative and quantitative content determination of macro-minor elements in Bryonia alba L. roots using flame atomic absorption spectroscopy technique. Adv Pharm Bull 6:285.

Kaur G, Asha W, Abdin MZ, Sarwat M, Ahmad A (2013) Molecular Network of Nitrogen and Sulphur Signaling in Plants. In: Sarwat et al. (eds.) Stress signaling in plants: genomics and proteomics perspective, vol. 1, Springer, New York, pp 240

Kaur M, Sharma S, Singh D (2018) Influence of selenium on carbohydrate accumulation in developing wheat grains. Commun Soil Sci Plant Anal 49:1650-1659

Kornaś A, Filek M, Sieprawska A, Bednarska-Kozakiewicz E, Gawrońska K, Miszalski Z (2019) Foliar application of selenium for protection against the first stages of mycotoxin infection of crop plant leaves. J Sci Food Agric 99:482-485

Kudre TG, Benjakul S, Kishimura H (2013) Comparative study on chemical compositions and properties of protein isolates from mung bean, black bean and bambara groundnut. J Sci Food Agric 93:2429-2436

Kutman UB, Yildiz B, Cakmak I (2011) Effect of nitrogen on uptake, remobilization and partitioning of zinc and iron throughout the development of durum wheat. Plant Soil 342:149-164

Lee BR, Jin YL, Avice JC, Cliquet JB, Ourry A, Kim TH (2009) Increased proline loading to phloem and its effect on nitrogen uptake and assimilation in water stressed white clover (Trifolium 
repens). New Phytol 182:654-663. https://doi.org/10.1111/j. 1469-8137.2009.02795.x

Lee BR, Zaman R, Avice JC, Ourry A, Kim TH (2015) Sulfur use efficiency is a significant determinant of drought stress tolerance in relation to photosynthetic activity in Brassica napus cultivars. Front Plant Sci 7:459

Lefsrud MG, Kopsell DA, Kopsell DE, Curran-Celentano J (2006) Irradiance levels affect growth parameters and carotenoid pigments in kale and spinach grown in a controlled environment. Physiol Plantar 127:624-631

Leng G (2017) Evidence for a weakening strength of temperaturecorn yield relation in the United States during 1980-2010. Sci Total Environ 605:551-558

Leng G, Hall J (2019) Crop yield sensitivity of global major agricultural countries to droughts and the projected changes in the future. Sci Total Environ 654:811-821

Lu Y (2018) Assembly and transfer of iron-sulfur clusters in the plastid. Front Plant Sci 9:336

Majeed S, Nawaz F, Naeem M, Ashraf MY, Ejaz S, Ahmad KS, Tauseef S, Farid G, Khalid I, Mehmood K (2020) Nitric oxide regulates water status and associated enzymatic pathways to inhibit nutrients imbalance in maize (Zea mays L.) under drought stress. Plant Physiol Biochem 155:147-160

Malik JA, Goel S, Kaur N, Sharma S, Singh I, Nayyar H (2012) Selenium antagonises the toxic effects of arsenic on mungbean (Phaseolus aureus Roxb.) plants by restricting its uptake and enhancing the antioxidative and detoxification mechanisms. Environ Exp Bot 77:242-248

Muneer S, Lee BR, Kim KY, Park SH, Zhang Q, Kim TH (2014) Involvement of sulphur nutrition in modulating iron deficiency responses in photosynthetic organelles of oilseed rape (Brassica napus L.). Photosynth Res 119:319-329. https://doi.org/10.1007/ s11120-013-9953-8

Nadeem M, Li J, Yahya M, Sher A, Ma C, Wang X, Qui L (2019) Research progress and perspective on drought stress in legumes. Rev Int J Mol Sci 20:1-32. https://doi.org/10.3390/ ijms20102541

Nair RM, Pandey AK, War AR, Hanumantharao B, Shwe T, Alam AKMM, Pratap A, Malik SR, Karimi R, Mbeyagala EK, Douglas CA (2019) Biotic and Abiotic Constraints in Mungbean Production-Progress in Genetic Improvement. Front Plant Sci 10

Nawaz F, Ashraf MY, Ahmad R, Waraich EA (2013) Selenium (Se) seed priming induced growth and biochemical changes in wheat under water deficit conditions. Biol Trace Elem Res 151:284-293

Nawaz F, Ahmad R, Ashraf MY, Waraich EA, Khan SZ (2015a) Effect of selenium foliar spray on physiological and biochemical processes and chemical constituents of wheat under drought stress. Ecotox Environ Saf 113:191-200

Nawaz F, Ashraf MY, Ahmad R, Waraich EA, Shabbir RN, Bukhari MA (2015b) Supplemental selenium improves wheat grain yield and quality through alterations in biochemical processes under normal and water deficit conditions. Food Chem 175:350-357

Nazar R, Iqbal N, Masood A, Syeed S, Khan NA (2011) Understanding the significance of sulphur in improving salinity tolerance in plants. Environ Exp Bot 70:80-87. https://doi.org/ 10.1016/j.envexpbot.2010.09.011

Noctor G, Mhamdi A, Chaouch S, Han YI, Neukermans J, MarquezGarcia BELEN, Queval G, Foyer CH (2012) Glutathione in plants: an integrated overview. Plant Cell Environ 35:454-484

Proietti P, Nasinia L, Del Buonoa D, D'Amatoa R, Tedeschinib E, Businellia D (2013) Selenium protects olive (Olea europaea L.) from drought stress. Sci Hortic 164:165-171

Raina SK, Govindasamy V, Kumar M, Singh AK, Rane J, Minhas PS (2016) Genetic variation in physiological responses of mungbeans (Vigna radiata (L.) Wilczek) to drought. Acta Physiol Plantar 38:263. doi: https://doi.org/10.1007/s11738016-2280-x

Ramos SJ, Rutzke MA, Hayes RJ, Faquin V, Guilherme LRG, Li L (2011) Selenium accumulation in lettuce germplasm. Planta 233:649-660

Rayman MP (2008) Food-chain selenium and human health: emphasis on intake. Br J Nutr 100:254-268

Reeves MA, Hoffmann PR (2009) The human selenoproteome: recent insights into functions and regulation. Cell Mol Life Sci 66:2457-2478

Reich M, Shahbaz M, Prajapati DH, Parmar S, Hawkesford MJ, De Kok LJ (2016) Interactions of sulfate with other nutrients as revealed by $\mathrm{H}_{2} \mathrm{~S}$ fumigation of Chinese cabbage. Front Plant Sci 7:541

Reis AFB, Almeida REM, Lago BC, Trivelin PC, Linquist BA, Favarin JL (2018) Aerobic rice system improves water productivity, nitrogen recovery and crop performance in Brazilian weathered lowland soil. Field Crops Res 218:59-68

Rossi L, Fedenia LN, Sharifan H, Ma X, Lombardini L (2018) Effects of foliar application of zinc sulfate and zinc nanoparticles in coffee (Coffea arabica L.) plants. Plant Physiol Biochem 135:160-166

Rubiales D, Mikić A (2015) Introduction: legumes in sustainable agriculture. Critic Rev Plant Sci 34:2-3

Sabatino L, Ntatsi G, Iapichino G, D’Anna F, De Pasquale C (2019) Effect of selenium enrichment and type of application on yield, functional quality and mineral composition of curly endive grown in a hydroponic System. Agronomy 9:207

Sachan HK, Krishna D, Chaudhary NK (2019) Sulphur Fertilization Effects on Yield and Nutrient Uptake of Mung bean [Vigna radiata (L.) Wilczek]. Ind J Agric Res doi: https://doi.org/10. 18805/IJARe.A-5399

Salvagiotti F, Miralles DJ (2008) Radiation interception, biomass production and grain yield as affected by the interaction of nitrogen and sulfur fertilization in wheat. Eur $\mathrm{J}$ Agron 28:282-290

Schonfeld MA, Johnson RC, Carver BF, Mornhinweg DW (1988) Water relations in winter wheat as drought resistance indicators. Crop Sci 28:526-531

Schultz HR (2003) Differences in hydraulic architecture account for near-isohydric and anisohydric behaviour of two field-grown Vitis vinifera L. cultivars during drought. Plant Cell Environ 26:1393-1405

Sehgal A, Sita K, Siddique KH, Kumar R, Bhogireddy S, Varshney RK, HanumanthaRao B, Nair RM, Prasad PV, Nayyar H (2018) Drought or/and heat-stress effects on seed filling in food crops: impacts on functional biochemistry, seed yields, and nutritional quality. Front Plant Sci 9:1705

Shahbaz M, Stuiver CEE, Posthumus FS, Parmar S, Hawkesford MJ, De Kok LJ (2014) Copper toxicity in Chinese cabbage is not influenced by plant sulphur status, but affects sulphur metabolism-related gene expression and the suggested regulatory metabolites. Plant Biol 16:68-78

Shahid MA, Balal RM, Khan N, Zotarelli L, Liu GD, Sarkhosh A, Fernández-Zapata JC, Nicolás JJM, Garcia-Sanchez F (2019) Selenium impedes cadmium and arsenic toxicity in potato by modulating carbohydrate and nitrogen metabolism. Ecotoxicol Environ Saf 180:588-599

Shehzad MA, Nawaz F, Ahmad F, Ahmad N, Masood S (2020) Protective effect of potassium and chitosan supply on growth, physiological processes and antioxidative machinery in sunflower (Helianthus annuus L.) under drought stress. Ecotoxicol Environ Saf 187: 109841

Shekari L, Aroiee H, Mirshekari A, Nemati H (2019) Protective role of selenium on cucumber (Cucumis sativus L.) exposed to 
cadmium and lead stress during reproductive stage role of selenium on heavy metals stress. J Plant Nutr 42:529-542

Shekhawat K, Shivay YS (2012) Residual effects of nitrogen sources, sulfur and boron levels on mungbean (Vigna radiata) in a sunflower (Helianthus annuus)-mungbean system. Arch Agron Soil Sci 58:765-776

Singh DP, Singh BB (2011) Breeding for tolerance to abiotic stresses in mung bean. J Food Legumes 24:83-90

Sors TG, Ellis DR, Na GN, Lahner B, Lee S, Leustek T, Pickering IJ, Salt DE (2005) Analysis of sulfur and selenium assimilation in Astragalus plants with varying capacities to accumulate selenium. Plant J 42:785-797

Speiser A, Silbermann M, Dong Y, Haberland S, Uslu VV, Wang S, Bangash SA, Reichelt M, Meyer AJ, Wirtz M, Hell R (2018) Sulfur partitioning between glutathione and protein synthesis determines plant growth. Plant Physiol 177:927-937

Stuiver CEE, Posthumus FS, Parmar S, Shahbaz M, Hawkesford MJ, Kok LJD (2014) Zinc exposure has differential effects on uptake and metabolism of sulfur and nitrogen in Chinese cabbage. J Plant Nutr Soil Sci 177:748-757

Taalab AS, Hellal FA, Abou-Seeda MA (2008) Influence of phosphatic fertilizers enriched with sulfur on phosphorus availability and corn yield in calcareous soil in arid region. Open J Appl Sci 1:105-115

Tabak M, Lepiarczyk A, Filipek-Mazur B, Bachara P (2019) Ammonium nitrate enriched with sulfur influences wheat yield and soil properties. Plant Soil Environ 65:211-217

Troy TJ, Kipgen C, Pal I (2015) The impacts of climate extremes and irrigation on US crop yields. Environ Res Lett 10:054013. https://doi.org/10.1088/1748-9326/10/5/054013

Turkan I, Bor M, Ozdemir F, Koca H (2005) Differential responses of lipid peroxidation and antioxidants in the leaves of droughttolerant $P$. acutifolius Gray and drought sensitive $P$. vulgaris L. subjected to polyethylene glycol mediated water stress. Plant Sci 168:223-231

Urbanek H, Kuzniak-Gebarowska E, Herka K (1991) Elicitation of defence responses in bean leaves by Botrytis cinereapolygalacturonase. Acta Physiol Plantar 13:43-50

Urton R, Hangs RD, Schoenau JJ, Grant CA (2018) The response of a high-yielding canola hybrid to sulfur fertilization in three contrasting Saskatchewan soils. J Plant Nutr 41:1957-1969

Usmani MM, Nawaz F, Majeed S, Shehzad MA, Ahmad KS, Akhtar G, Aqib M, Shabbir RN (2020) Sulfate-mediated Drought tolerance in Maize involves Regulation at physiological and Biochemical Levels. Sci Rep 10:1-13

Van Rossum MWPC, Alberda M, van der Plas LHW (1997) Role of oxidative damage in tulip bulb scale micropropagation. Plant Sci 130:207-216

Vazin F (2012) Effect of zinc sulfate on quantitative and qualitative characteristics of corn (Zea mays) in drought stress. Cercet Agron Moldov 45:15-24

White PJ, Bowen HC, Parmaguru P, Fritz M, Spracklen WP, Spiby RE, Meacham MC, Mead A, Harriman M, Trueman LJ, Smith BM (2004) Interactions between selenium and sulphur nutrition in Arabidopsis thaliana. J Exp Bot 55:1927-1937

Yao X, Chu J, Liang L, Geng W, Li J, Hou G (2012) Selenium improves recovery of wheat seedlings at rewatering after drought stress. Russ J Plant Physiol 59:701-707

Zhao Q, Wu Y, Gao L, Ma J, Li CY, Xiang CB (2014) Sulfur nutrient availability regulates root elongation by affecting root indole-3acetic acid levels and the stem cell niche. J Integr Plant Bio $56: 1151-1163$

Publisher's Note Springer Nature remains neutral with regard to jurisdictional claims in published maps and institutional affiliations. 